\title{
Updated picture of the Ligurian and Sub-Ligurian units in the Mt. Amiata area (Tuscany, Italy): elements for their correlation in the framework of the Northern Apennines
}

\author{
Michele Marroni $(*),(* * *)$, Enrico Pandeli $(* *),(* * * *)$, Luca Pandolfi $(*),(* * *)$ \& Rita Catanzariti $(* * *)$
}

\section{ABSTRACT}

The Mt. Amiata region (Southern Tuscany, Italy) represents the southernmost area of the Northern Apennines in which different lithologies belonging to the Ligurian and Sub-Ligurian units crop out widely. This paper provides an update on the stratigraphic, paleontological and structural features of the Ligurian and Sub-Ligurian units in the Mt. Amiata area by integrating new data from the Regional Geological Mapping project with those available from the existing literature.

In the study area, the Sub-Ligurian units are represented by the Canetolo unit, which comprises the middle Eocene (Zone NP15) Argille e Calcari and Vico Fms showing heteropic relationships. The Ligurian units are represented by the Ophiolitic and Santa Fiora units. The Ophiolitic unit consists mainly of Early Cretaceous Palombini Shale associated with scattered Middle-Late Jurassic ophiolites. The age of the Palombini Shale spans from late Hauterivian-Barremian Zone CC5 to Aptian Zone CC7 of SissingH (1977). The Ophiolitic unit overlies the Santa Fiora unit consisting of the Pietraforte Fm and Varicoloured Shales topped by the Santa Fiora Fm. The Pietraforte Fm shows heteropic relationships with the Varicoloured Shale, and both formations can be referred to the ?Aptian to middle Coniacian. The age of the Santa Fiora Fm seems to span from the late Coniacian-early Santonian (Zone CC14) to middle-late Campanian (Zones CC21-CC22).

Structural analyses indicate that all the Ligurian and Sub-Ligurian units experienced complex polyphase deformation through several folding phases during the closure of the Ligurian-Piemontese oceanic basin and the subsequent continental collision, which began in the middle Eocene. The Ligurian and Sub-Ligurian units now come into contact through low-angle shear zones developed during the last deformation phase identified in these units, i.e. middle Miocene extensional tectonics. This tectonic phase produced strong delamination through low-angle faults with staircase geometry, so that not only several stratigraphic levels but also entire tectonic units were omitted.

Despite the extensional tectonics, the collected stratigraphic and structural data suggest a correlation between the Ligurian and SubLigurian units of the Mt. Amiata area and the units cropping out in Southern Tuscany and the Ligurian-Emilian Apennines.

KEY WORDS: Ligurian and Sub-Ligurian units, tectonics, stratigraphy, Mt. Amiata area, Southern Tuscany-Italy.

\section{INTRODUCTION}

The Mt. Amiata region (SE Tuscany, Italy) represents the southernmost area of the Northern Apennines in which the different lithologies of the Ligurian and Sub-

(*) Dipartimento di Scienze della Terra, Università di Pisa Via S. Maria, 53 - 56126 Pisa, Italy. Corresponding author: e-mail: marroni@dst.unipi.it

(**) Dipartimento di Scienze della Terra, Università di Firenze

(***) Istituto di Geoscienze e Georisorse, CNR, Pisa

$(* * * *)$ Istituto di Geoscienze e Georisorse, CNR, Florence.
Ligurian units crop out widely (fig. 1a). These units provide important insights into the pre-collisional geodynamic evolution of the Northern Apennines, mainly because they represent fragments of the LigurianPiemontese oceanic domain, the closure of which originated the collisional belt.

Although the outcrops of the Mt. Amiata area are of poor quality and less continuous than those of the Ligurian and Emilian Apennines, it is nonetheless one of the best areas in the Northern Apennines in which to study the stratigraphic, paleontological and structural features of the Ligurian and Sub-Ligurian units.

Past studies on the Ligurian and Sub-Ligurian units of this area have generally focused on stratigraphic features (PANDELI et alii, 2005 and references therein). Recent geological surveys of the Mt. Amiata area, in the framework of the Regional Geological Mapping project funded by the Regione Toscana, produced not only a new 1:10.000 geological map of the Mt. Amiata area but also yielded a complete set of new data on the Ligurian and Sub-Ligurian units.

This paper provides a summary of the stratigraphic, paleontological and structural features of the Ligurian and Sub-Ligurian units in the Mt. Amiata area by integrating new data from the Regional Geological Mapping project (REgIONE TOSCANA, 2014) with those available from the existing literature (CALAMAI et alii, 1970; BETTELLI et alii, 1980; BRUNACCI et alii, 2003; BATINI et alii, 2003; PANDELI et alii, 2005). This compilation provides an opportunity to compare the Ligurian and Sub-Ligurian cropping out in the Mt. Amiata area with those cropping out to the west and north, i.e. in Southern Tuscany and the Ligurian-Emilian Apennines.

\section{GEOLOGICAL SETTING OF THE MT. AMIATA AREA}

The Mt. Amiata area is located in the inner part of the Northern Apennine belt (fig. 1a), just $100 \mathrm{~km}$ northwest of the Olevano-Antrodoco line, i.e. the geological boundary between the Northern and Central Apennines. This area is characterized by a 300-190 Ka-old volcano (FERRARI et alii, 1996) built up over an uplifted substratum belonging to the so-called "Montalcino-Mt. Amiata-Mt. Razzano Ridge" (fig. 1b). This ridge corresponds to a north-south trending horst bounded by two main grabens filled by late Miocene to Quaternary continental to marine deposits known, from west to east, as the Cinigiano-Baccinello and Siena-Radicofani basins. The ridge 

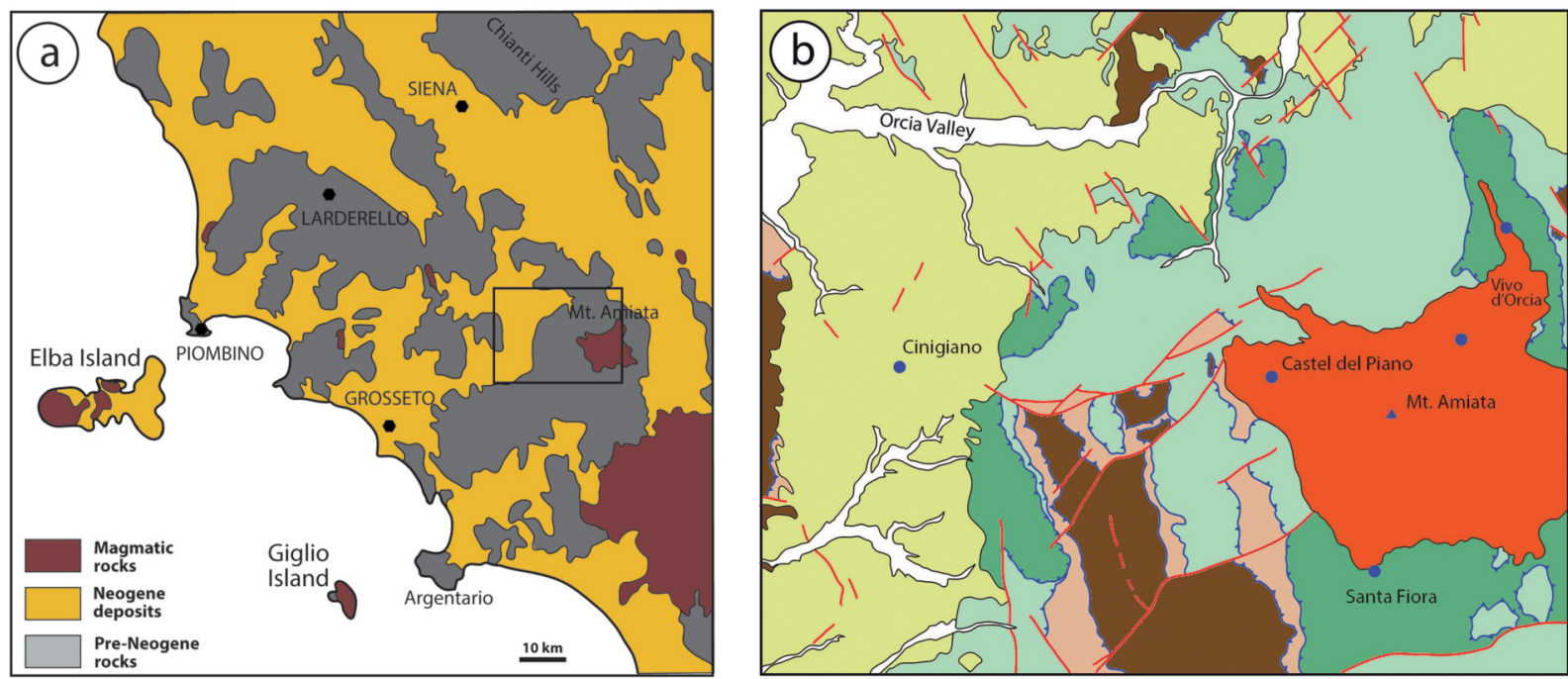

LEGEND

Alluvial deposits

Mt. Amiata Volcanics Late MioceneOphiolitics Unit

Fig. 1 - Tectonic sketch map of Tuscany $(a)$ and tectonic sketch map of the Mt. Amiata area $(b)$. The location of the Mt. Amiata area is shown in the tectonic sketch map of Tuscany.

consists of a stack of tectonic units unconformably overlain by late Miocene to Quaternary sedimentary deposits.

This tectonic setting is the result of the long geodynamic evolution that led to the formation of the Northern Apennine collisional belt. This evolution started with the opening of the Jurassic Ligurian-Piemontese oceanic basin, located between the continental margins of the Eurasian and Adria plates. The Ligurian-Piemontese basin was affected by a Late Cretaceous-middle Eocene intraoceanic subduction (BORTOLOTTI et alii, 1970; Elter, 1975; Principi \& Treves, 1984; AbBAte et alii, 1986; BortolotTi et alii, 1990; CARMignani \& KLIGFIELD, 1990; CARMIGNANI et alii, 1995; BARCHI et alii, 2001; CARMIGNANI et alii, 2001; MOLLI, 2008; MARRONI et alii, 2010). The Ligurian units represent the remnants of the accretionary wedge developed during intraoceanic subduction; these have been divided into Internal and External units representing the oceanic basin and the ocean-continent transition at the Adria plate margin respectively (ELTER, 1975; TREVES, 1984; MARRONI et alii, 2001). The Sub-Ligurian units are thought to represent the thinned continental margin of the Adria plate close to the ocean-continent transition (TREVES, 1984; MARRONI et alii, 2001). Intraoceanic subduction was followed in the middle Eocene by the onset of continental collision. Continental collision was characterized by the progressive migration of the deformation front toward the eastern domains of the Adria plate; this resulted in the development of a fold-and-thrust belt composed of structural units (Tuscan, Umbrian and Romagnan units) derived from the Adria domains and deformed with an $\mathrm{E}$ to NE vergence (e.g. Costa et alii, 1998; BARCHI et alii, 2001). From the Oligocene to the present day this deformation was accompanied by the development of foreland basins (foredeep and piggy-back basins of ORI \& FRIEND, 1984) that were successively incorporated into the collisional belt (RICCI LuCCHI, 1986; ARUTA et alii, 1998; BARCHI et alii, 2001). During the middle Miocene the uppermost structural levels of the Apennines were affected by lowangle extensional faults formed due to the overthickening of the collisional belt (CARMIGNANI \& KLIGFIELD, 1990; DECANDIA et alii, 1993). From the late Miocene onward, the migration of the deformation front was followed in space and time by extensional tectonic deformation characterized by the development of high-angle normal faults and coeval marine to continental basins (e.g. ELTER et alii, 1975; AMBrosetTI et alii, 1978; LAVECCHIA et alii, 1987; Bertini et alii, 1991; MARTINI \& SAGRI, 1993; MARTINI et alii, 2001).

In the framework of the Northern Apennines, the Mt. Amiata area (fig. 1b) is the southernmost area in which the uppermost structural levels of the collisional belt are well preserved (CALAMAI et alii, 1970; BETTELLI et alii, 1980; BRUNACCI et alii, 2003; BATINI et alii, 2003; PANDELI et alii, 2005). These levels are represented by the Ligurian and Sub-Ligurian units (fig. 2). The Ligurian units consist of Jurassic ophiolites and Cretaceous-Early Tertiary sedimentary successions, whereas the Sub-Ligurian units comprise only Eocene deposits (CALAMAI et alii, 1970; PANDELI et alii, 2005). These units experienced a complex structural evolution involving very low-grade metamorphism or no metamorphic imprint (FRANCESCHELLI et alii, 1994 and references therein). The Ligurian and Sub-Ligurian units overlie the Tuscan Nappe (CALAMAI et alii, 1970; BATINI et alii, 2003; BROGI, 2004a), which is well exposed in some tectonic windows (fig. 1b) located west (Mt. Aquilaia-Mt. Labbro) and east of Mt. Amiata (Poggio Zoccolino, Mt. Civitella-Castell'Azzara-Mt. Elmo). The latter unit consists of a Mesozoic to Tertiary passive margintype sedimentary succession (FAzzUOLI et alii, 1994 and references therein) comprising Late Triassic-Early Jurassic continental and shallow-water deposits showing a transition to Middle Jurassic-late Oligocene pelagic deposits topped by late Oligocene-early Miocene foredeep siliciclastic turbidites (Macigno Fm). Most of the shear zones at the top of or inside the Tuscan Nappe can be considered low-angle thrusts, as suggested by local tectonic doubling of the successions (e.g. Mt. Aquilaia, Poggio Zoccolino and subsurface of Bagnore in BROGI \& LAZZAROTTO, 2002; PANDELI et alii, 2005). The logs of deep boreholes indicate that at depth the Tuscan Nappe lies tectonically above the Tuscan Metamorphic units consisting of ?Devonian to Upper Permian formations capped by Triassic Verrucano sediments (PANDELI et alii, 1988; ElTER \& PANDELI, 1991). 


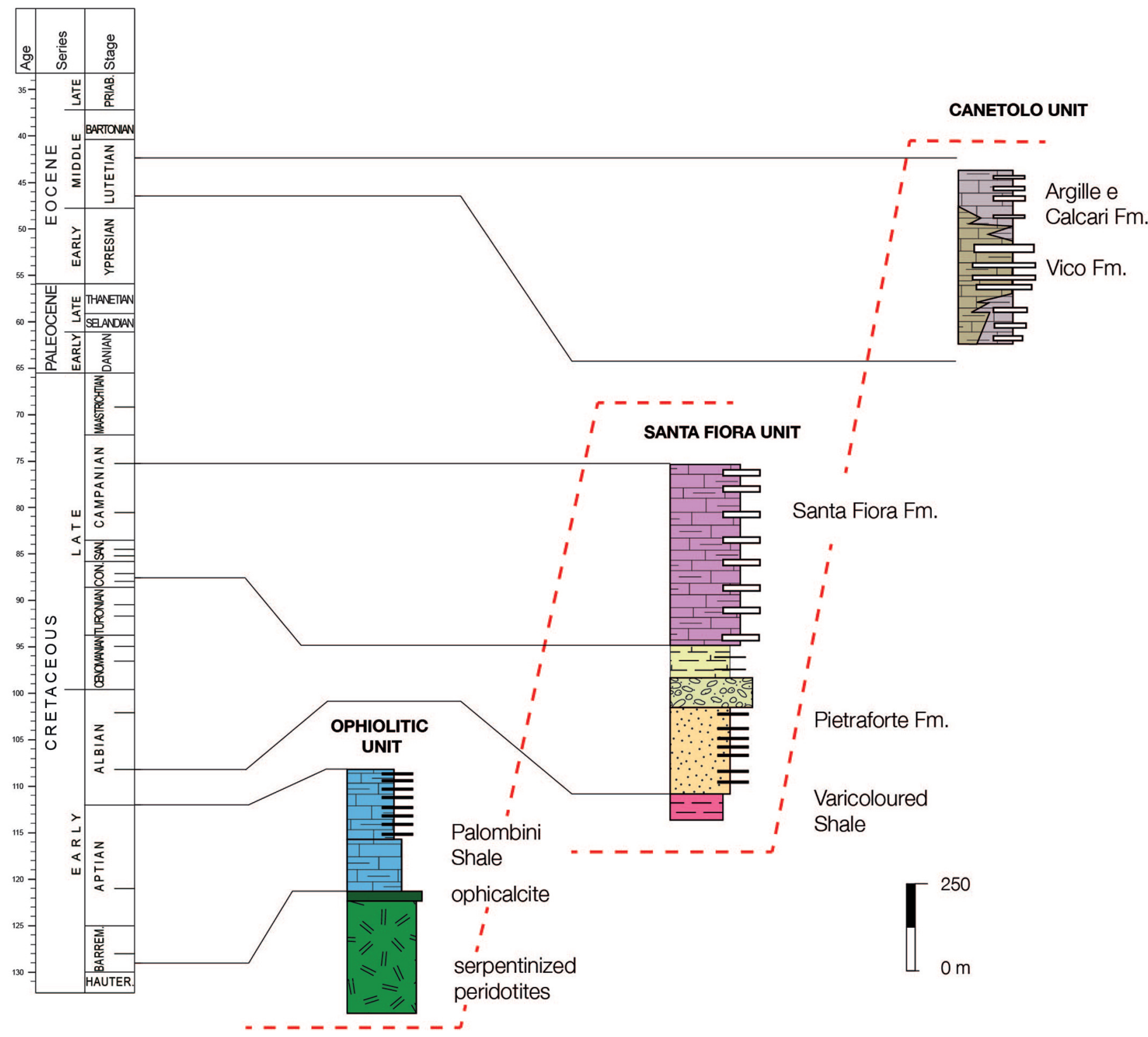

Fig. 2 - Chronostratigraphic sketch of the Sub-Ligurian and Ligurian units in the Mt. Amiata area.

Outcrops and subsurface data throughout Southern Tuscany reveal that the Tuscan Nappe, as well as the overlying Ligurian and Sub-Ligurian units, is often affected by tectonic delamination ("Serie ridotta" in DeCANDia et alii, 1993, 2001; BERTINI et alii, 1991 and many others). This delamination is the result of the development of low-angle faults with staircase geometry that led to the omission of several stratigraphic levels. As a result of the tectonic delamination, the Internal Ligurian units of the Mt. Amiata area lie directly above the lowermost structural levels of the Tuscan Nappe, represented by Late Triassic evaporites (e.g. CALAMAI et alii, 1970; PANDELI et alii, 2005; BROGI 2004b). Some authors suggest that this peculiar tectonic setting may be ascribed to extensional tectonic deformation of the uppermost structural levels of an overthickened nappe stack during middle Miocene compression (CARMignani \& Kligfield, 1990; DeCANDia et alii, 1993, 2001; BERTINI et alii, 1991).
Starting in the late Tortonian, further regional extensional, post-contractional tectonic activity produced highangle faulting with a main NW-SE and N-S strike, with the development of horst (e.g. the Montalcino-Mt. Amiata-Monte Razzano Ridge) and graben (e.g. the Cinigiano-Baccinello and Siena-Radicofani basins) structures (Elter et alii, 1975; Pasquarè et alii, 1983; Martini \& SAGRI, 1993; MARTINI et alii, 2001). As a result of the progressive eastward migration of regional extensional tectonics, the base of the sedimentary deposits that unconformably overlain the Ligurian, Sub-Ligurian and Tuscan units is assigned to the late Tortonian and the early Pliocene in the Baccinello-Cinigiano and the Siena-Radicofani basins respectively. The horst and graben structures were dissected by SW-NE striking sub-vertical faults characterized by strike- and obliqueslip kinematics with predominantly left-lateral movement (Liotta, 1991; Brogi \& Fabbrini, 2009). The 

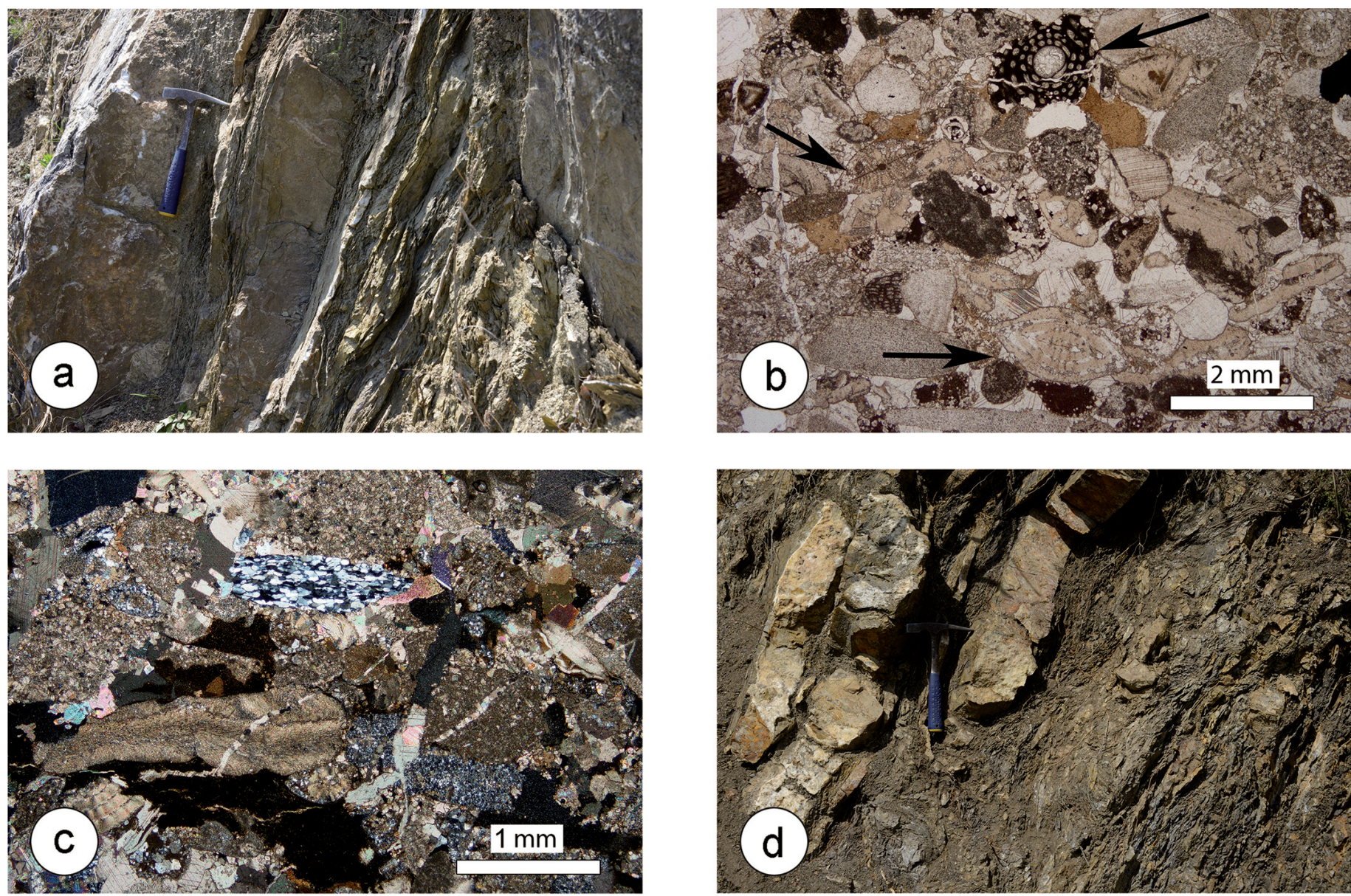

Fig. 3 - Stratigraphic features of the the Canetolo unit succession: $a$ ) outcrop of Vico Fm; $b$ ) Photomicrograph of the fossil-bearing Vico Fm arenites; $c$ ) Photomicrograph of Vico Fm Arenites; $d$ ) outcrop of argille e Calcari Fm.

strike-slip faults were associated with fissure eruptions and domes such as those that originated the Quaternary Mt. Amiata volcano (Mazzuoli \& Pratesi, 1983; GiaNELLI et alii, 1988; FERRARI et alii, 1996). Possible minor compressive pulses affected the Mt. Amiata region in the middle-late Pliocene (BoccAlETTI \& SANI, 1998; BONINI \& SANI, 2002), but these did not significantly affect the geometry of the tectonic stack (e.g. no doublings or detachments).

\section{THE SUB-LIGURIAN UNITS}

In the Mt. Amiata area, the Sub-Ligurian units are represented by the Canetolo unit only, which crops out in the surroundings of the Monte Aquilaia-Monte Labbro tectonic window located SW of Mt. Amiata (fig. 2). These units are always sandwiched between the Tuscan Nappe at the base and the Ligurian units at the top. Due to Miocene extensional tectonics, the Canetolo unit can be overlain by either the Santa Fiora unit or the Ophiolitic unit (fig. 2). In particular, two main outcrops of the Canetolo unit occur along the ENE-SSW strike-slip fault located south of Monticello Amiata. The Canetolo unit shows evidence of polyphase deformation developed under medium to high diagenetic conditions (FRANCESCHELLI et alii, 1994).

\section{The Canetolo unit}

The Canetolo unit shows a succession consisting of the Argille e Calcari Fm and Vico Fms (cf. Argille e Calcari di Canetolo and Calcari di Groppo del Vescovo, PERILLI et alii, 2009 and references therein). The formations show heteropic relationships. The thrusts and folds that strongly deform the entire Canetolo unit make it difficult to assess the true thickness of the succession. The apparent thickness is about $200-300 \mathrm{~m}$.

\section{i) Stratigraphy}

The Vico Fm (fig. 3a) is represented by medium- to very-thick beds of carbonate turbidites with Ta-e, Tb-e and minor Ta/c-e Bouma sequences. These turbidites are represented by continuous beds of bioclast-rich calcarenites or calcirudites, limestones and marlstones ranging from 1 to $5 \mathrm{~m}$ in thickness. Bioclast fragments can be discerned in the calcarenites even with a magnifying lens. Amalgamation surfaces and erosional bases are locally present in the coarser beds. The carbonate turbidites are interbedded with thin to thick beds of black hemipelagic carbonate-free shales.

In thin section the arenites from the Vico Fm are sublitharenites characterized by a hybrid and mixed siliciclastic-carbonate framework composition (fig. 3b,c). The carbonate intrabasinal fragments are mainly bioclasts of 


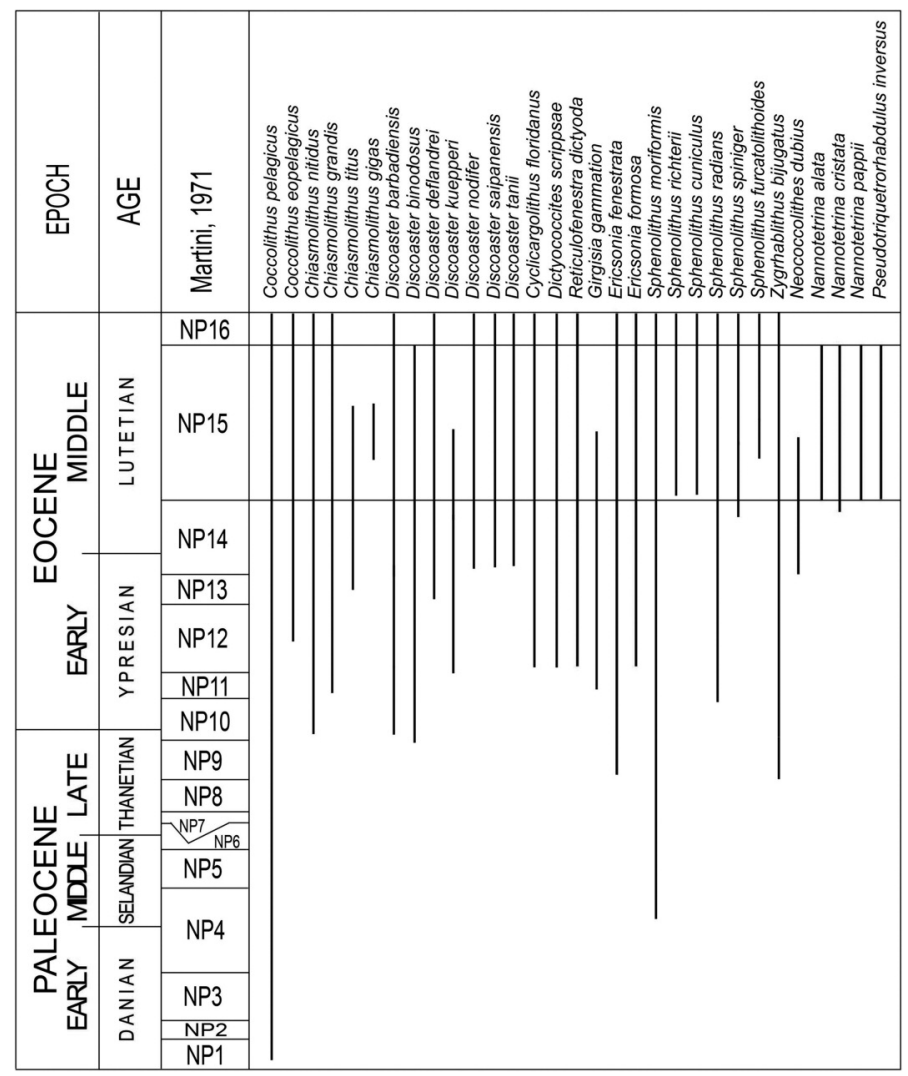

Fig. 4 - Stratigraphic distribution of calcareous nannofossil taxa identified in the Argille e Calcari Fm.

the same benthic (Orbitoides, Nummulites, Discocyclina) and planktonic (e.g. Globoratalia and Globigerina) foraminifera found in the fragments of lamellibranch; red algae and sponges can be also recognized. A few intrabasinal soft mudstone clasts are sometimes present. Extrabasinal carbonate fragments mainly consist of mudstone, radiolaria-bearing wackestones and dolostones. In this group, silicified and partly silicified fragments of radiolaria-bearing wackestones probably derived from cherty limestones are possibly included. The extrabasinal siliciclastic arenite framework is characterized by mono- and polycrystalline quartz, minor plagioclase and K-feldspar monocrystals. Coarse-grained lithic fragments of granitoids and porphyritic rhyolites, as well as low-grade metamorphic rock fragments, are also present. There are no ophiolite-derived rock fragments.

The Argille e Calcari Fm consists mainly of hemipelagic carbonate-free shales with subordinate carbonate turbidites. The carbonate turbidites generally consist of thin to thick beds of fine-grained limestones generally showing no sedimentary structures and ranging from $30 \mathrm{~cm}$ to $1 \mathrm{~m}$ in thickness (fig. 3d). Very thick (from tens of $\mathrm{cm}$ to $4-5 \mathrm{~m}$ ) beds of carbonate turbidites also occur. These very thick turbidites showing Tb-e and Tc-e Bouma intervals comprise limestone and marly limestone beds characterized by sedimentary structures such as plane laminae and ripples. These turbidites sometimes have a hybrid medium- to coarse-grained arenitic base containing a mixture of benthic (Orbitoides, Nummulites and Discocyclina) and planktonic (Globorotalia and Globigerina) foraminifera bioclasts. The turbidites were deposited by low-density turbidity currents.
Subordinate siliciclastic turbidites occur as $5-30 \mathrm{~cm}-$ thick beds of quartz-rich arenites and siltstones displaying incomplete Tb-e or Tc-e Bouma sequences. The arenitic beds occur locally (e.g. SW of Bagnore) as coarsegrained amalgamated bodies characterized by Ta, Ta/c-e and Ta/d-e Bouma intervals.

The carbonate and siliciclastic turbidites are intercalated in very thick beds of hemipelagic, carbonate-free black shales.

\section{ii) Paleontological Dating}

PANDELI et alii (2005) dated the Argille e Calcari Fm in the Mt. Amiata area to the early-middle Eocene on the basis of foraminifera and calcareous nannofossil assemblages (fig. 4). Foraminifera are represented by Acarinina bullbrooki, Morozovella aragonesi, Morozovella crassata, Turborotalia cerroazulensis; the nannofossil assemblages contain Coccolithus pelagicus, Discoaster kuepperi, Reticulofenestra dictyoda, Reticulofenestra samodurovii, Sphenolithus radians and Zygrhablithus bijugatus. The Cretaceous nannofossil assemblages found in limestone samples were considered reworked, as they contain species referable to late Campanian Zones CC22-CC23 of SISSINGH (1977): Aspidolithus parcus constrictus, Calculites obscurus, Ceratolithoides aculeus, Cribrosphaerella erhenbergii, Manivitella pemmatoidea, Prediscosphaera cretacea, Prediscosphaera intercisa, Quadrum sissinghii, Quadrum trifidum, Reinhardtites levis and Watznaueria barnesae.

In order to analyze the calcareous nannofossil content and better define the age of the Canetolo unit, we sampled the Argille e Calcari Fm south of Monticello Amiata and the Vico Fm in the area southeast of Montegiovi. The samples, prepared as smear slides (Bown \& YouNG, 1998), were studied under cross-polarized light at 1250X.

Calcareous nannofossils were abundant and moderately well preserved (fig. 5). The easily identified species are Chiasmolithus gigas, Chiasmolithus grandis, Chiasmolitus nitidus, Chiasmolithus titus, Clausicoccus fenestratus, Coccolithus eopelagicus, Coccolithus pelagicus, Cyclicargolithus floridanus, Ericsonia formosa, Discoaster barbadiensis, Discoaster binodosus, Discoaster deflandrei, Discoaster kuepperi, Discoaster nodifer, Discoaster saipanensis, Discoaster tanii, Girgisia gammation, Dictyococcites scrippsae, Nannotetrina alata, Nannotetrina cristata, Nannotetrina pappii, Neococcolithes dubius, Pseudotriquetrorhabdulus inversus, Reticulofenestra dictyoda, Sphenolithus cuniculus, Sphenolithus furcatolithoides, Sphenolithus radians, Sphenolithus spiniger, Sphenolithus richterii and Zygrhablithus bijugatus (fig. 4). Due to the concomitant presence of $C$. gigas, $N$. cristata, $S$. cuniculus and $S$. furcatolithoides, the sampled Argille e Calcari Fm can be assigned to the upper part of the Lutetian (middle Eocene) Zone NP15 of MARTINI (1971) (fig. 6). The samples collected in the uppermost, finer portion of the turbidites in the Vico Fm contain only Cretaceous calcareous nannofossil assemblages referable to the Aptian-Albian (Eprolithus floralis, Brarudosphaera spp., Prediscosphaera columnata, Nannoconus spp., Assipetra terebrodentarius, Biscutum spp., and Watznaueria spp.) the Coniacian (Micula staurophora, Eiffellithus eximius and Watznaueria spp.) and the Campanian (Aspidolithus parcus, Calculites obscurus, Micula spp. and Watznaueria spp.). The presence of Nummulites sp. in the calcarenites associated 

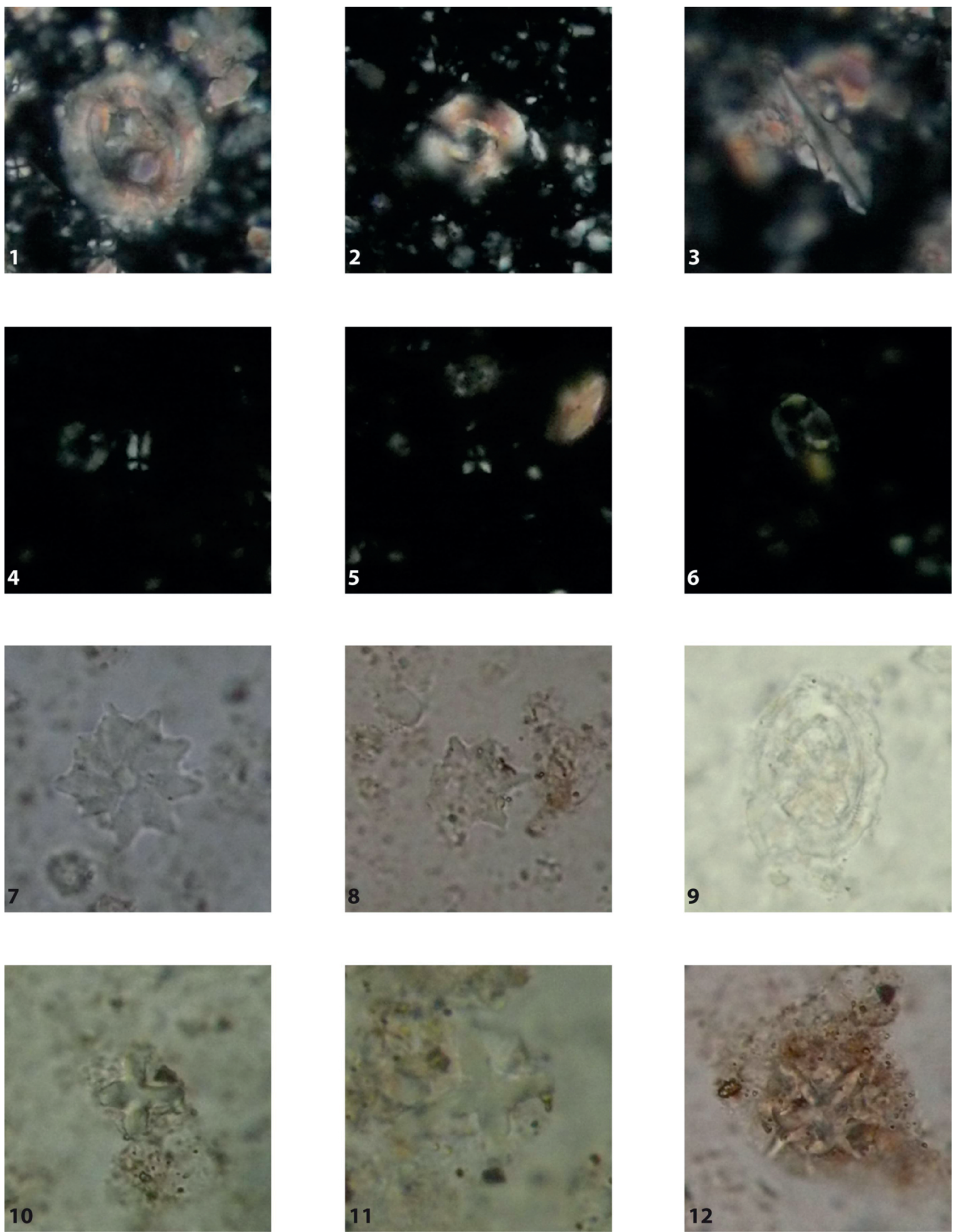

Fig. 5 - Photomicrographs of selected calcareous nannofossils identified in the Argille e Calcari Fm. All specimens X1200: 1) Chiasmolithus gigas, crossed nicols. Sample CDP50; 2) Reticulofenestra dictyoda, crossed nicols. Sample CDP46; 3) Pseudotriquetrorhabdulus inversus, crossed nicols. Sample CDP50; 4) Sphenolithus furcatolithoides, crossed nicols. Sample CDP50; 5) Sphenolithus spiniger, crossed nicols. Sample CDP48; 6) Neococcolithes dubius, crossed nicols. Sample CDP48; 7) Discoaster barbadiensis, parallel light. Sample CDP48; 8) Discoaster saipanensis, parallel light. Sample CDP48; 9) Chiasmolithus grandis, parallel light. Sample CDP51; 10) Nannotetrina cristata, parallel light. Sample CDP48; 11) Nannotetrina alata, parallel light. Sample CDP46; 12) Nannotetrina pappii, parallel light. Sample CDP48. 


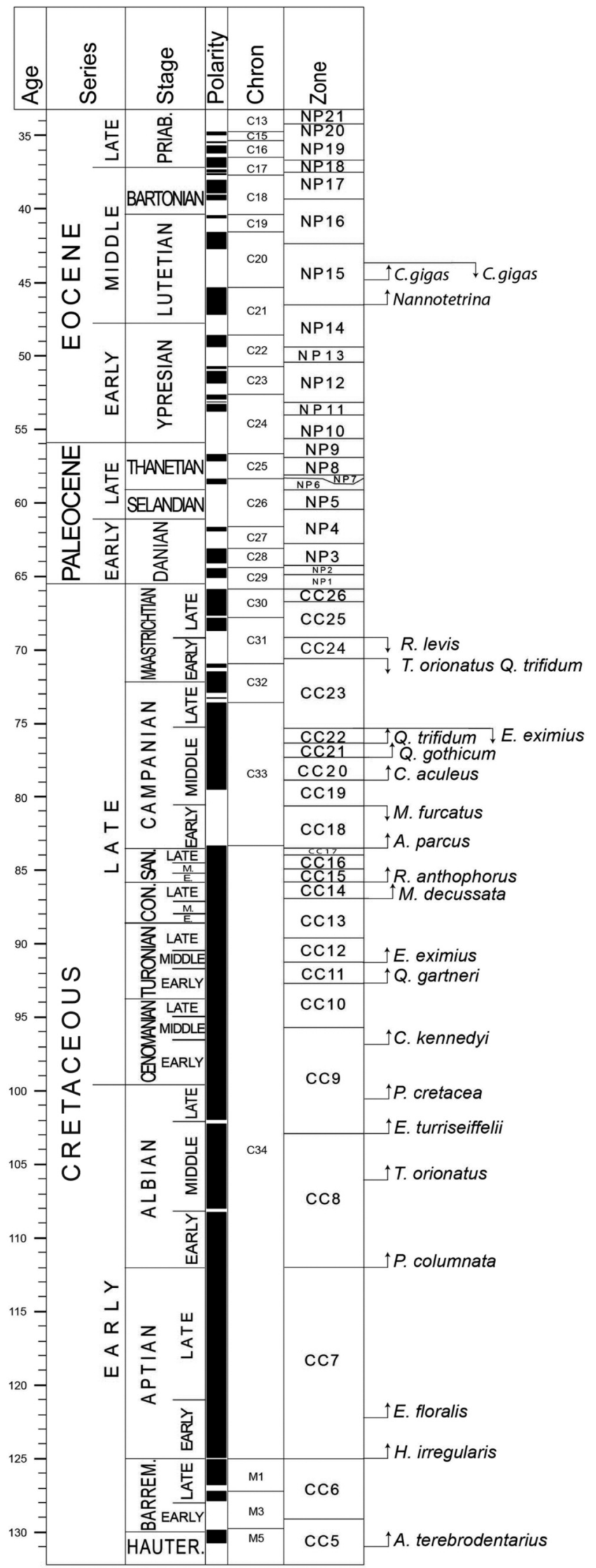

Fig. 6 - Calcareous nannofossil zonal system with the main biohorizons used to date the Argille e Calcari Fm, the Santa Fiora Fm, the Pietraforte Fm, the Varicoloured Shales and the Palombini Shale. The NP Zones are after MARTINI (1971), the CC Zones after SISSINGH (1977), and the chronostratigraphic scheme after GRADSTEIN et alii (2012). with the limestones and marlstones sampled for the calcareous nannofossil study suggests that the Cretaceous species are reworked.

\section{iii) Deformation History}

The deformation history of the Canetolo unit involved three deformation phases (D1 to D3). The deformation history has been reconstructed mainly in the Argille e Calcari Fm, where the layered shale and limestone beds better reveal the structural evolution.

Millimeter-thick veins developed parallel to the bedding prior to folding. These veins show a mosaic texture with calcite infilling.

The D1 phase is mainly represented by an S1 scaly foliation parallel to the bedding (fig. 7a). This foliation is associated with rare F1 isoclinal folds with similar geometry. The limbs of the F1 folds are generally affected by brittle boudinage with recrystallization of calcite fibers in the space opened among the boudins.

The D2 phase is pervasive and can be detected in all the outcrops of this unit. The D2 phase was mainly responsible for the development of asymmetric, overturned F2 folds (fig. 7b) with approximately parallel geometry (classes 1b, 1c and 2 of RAMSAY, 1967). The A2 axes trend NNE-SSW, as revealed by the measured axes and the dispersion of the bedding poles (fig. 7c). The hinges of F2 folds are rounded, whereas the interlimb angles range from $40^{\circ}$ to $100^{\circ}$. These folds are characterized by a low-angle PA2 axial plane parallel to a well developed S2 foliation that can be classified as disjunctive cleavage. The S0/S2 intersection lineations originate a typical pencil cleavage (fig. 7d). The F2 folds are associated with low-angle thrusts marked by cataclasites showing a top-to-E sense of shear.

Gentle F3 folds showing a clear N-S trend developed during the D3 phase. The F3 folds show an approximately parallel geometry (classes $1 \mathrm{~b}, 1 \mathrm{c}$ and 2 of RAMSAY, 1967) and a subvertical PA3 axial plane. These structures are responsible for the further dispersion of the bedding, as shown by the stereonet in fig. 7e. The interlimb angles range from $90^{\circ}$ to $160^{\circ}$, whereas the A3 axes trend from NNE/SSW to NNW/SSE (fig. 7e). F3 folds are characterized by a well-spaced subvertical fracture cleavage.

\section{THE LIGURIAN UNITS}

The Ligurian units in the Mt. Amiata area are represented by two units, the Ophiolitic unit (cf. LigurianMaremma Group of BRUNACCI et alii, 1983; Upper Ophiolitic unit of BERTINI et alii, 2000; Ophiolitiferous unit of PANDELI et alii, 2005) and the Santa Fiora unit (cf. Formazione argilloso-calcarea of BETTELLI, 1980, 1985). These two units come into contact through subhorizontal, low-dipping shear zones that can be interpreted as low-angle normal faults developed during middle Miocene extensional tectonics (BERTINI et alii, 1991; BROGI, 2004a and b). Both Ligurian units are characterized by a complex structural setting developed through polyphase deformation generally under medium to high diagenetic conditions in the Santa Fiora unit and very low-grade metamorphism (anchizone) in the Ophiolitic unit (FRANCESCHELLI et alii, 1994). 

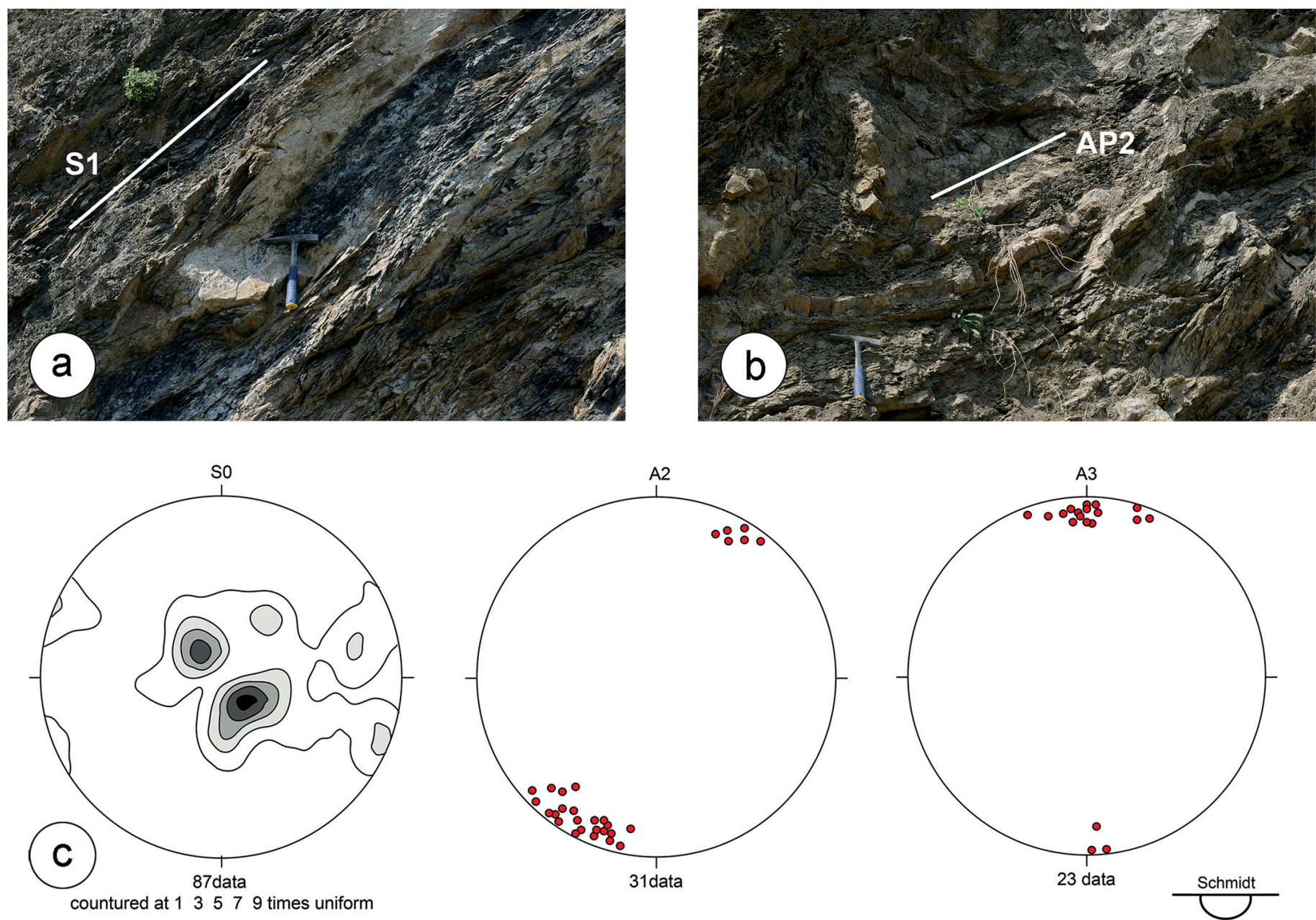

Fig. 7 - Structural features of the Canetolo unit: a) F1 fold in the Argille e Calcari Fm (S1: foliation of the D1 phase); $b$ ) F2 fold (AP2: axial plane of the F2 folds); $c$ ) stereonets of $\mathrm{S} 0, \mathrm{~A} 2$ and $\mathrm{A} 3$ data from the Canetolo unit.

\section{The SANTA FIORA UNIT}

The Santa Fiora units succession includes Varicoloured Shale, the Pietraforte Fm and the Santa Fiora Fm. The Varicoloured Shales and the Pietraforte Fm are characterized by stratigraphic, probably heteropic relationships, whereas the Santa Fiora Fm is the youngest deposit in this unit. In the Piancastagnaio and Torrente Senna area, small dykes and sills of basic magmatic bodies ("Selagiti" Auctt.) of Cretaceous age are intruded in the Varicoloured Shales (BRUNACCI et alii, 1983). A map-scale structure shows the Santa Fiora Fm at its core, with the Varicoloured Shales and the Pietraforte Fm at both the base and the top, as seen in the Seggiano area. This structure can be considered a recumbent synform with the core, represented by the Santa Fiora Fm, bounded by well developed overturned and normal limbs. Along both limbs the Santa Fiora Fm is locally detached from the Varicoloured Shale/Pietraforte Fm couple (tectonic "Pietraforte sub-unit" in PANDELI et alii, 2005). This detachment likely occurred while the fold developed, but it was subsequently reworked by low-angle normal faults. Despite the strong deformation, the original stratigraphic relationship between the Santa Fiora Fm and the Varicoloured Shale/Pietraforte Fm couple is clearly visible in some places (e.g. CostANTINI et alii, 1977; PANDELI et alii, 2005). Folding and the scattered distribution of out- crops make it difficult to correctly assess the true thickness of the complete succession, which is estimated at not less than $1000 \mathrm{~m}$.

\section{i) Stratigraphy}

The Varicoloured Shales is characterized by massive beds of manganesiferous shale with typical grey, greygreenish, black and reddish colours. Thin-bedded silicified limestones are intercalated within the shale.

In the Mt. Amiata area the Pietraforte Fm is represented by turbidite deposits occurring in three different lithofacies.

The first, most widespread lithofacies (arenaceous and arenaceous-pelitic lithofacies in PANDELI et alii, 2005) is represented by massive to graded turbidites consisting of medium- to thick-bedded (locally more than $10 \mathrm{~m}$ ) arenites and siltites with an $\mathrm{a} / \mathrm{p}$ ratio generally $>4$ (fig. $8 \mathrm{a}$ ). Fine- to medium-grained rudites ("Cicerchina" Auctt.), as well as clay chips, are quite common at the base of the thickest arenite beds. The turbidite beds, which are generally lenticular and amalgamated, are characterized by $\mathrm{Ta}$, Ta-c, Ta/c-e, Tab/de and Ta-d Bouma sequences. There are also rare intercalations of thin-bedded shales. The coarse beds are generally lenticular and amalgamated, and can be ascribed to high-density turbidity currents (cfr. F5 and F8 facies of MUTTI, 1992). According to 

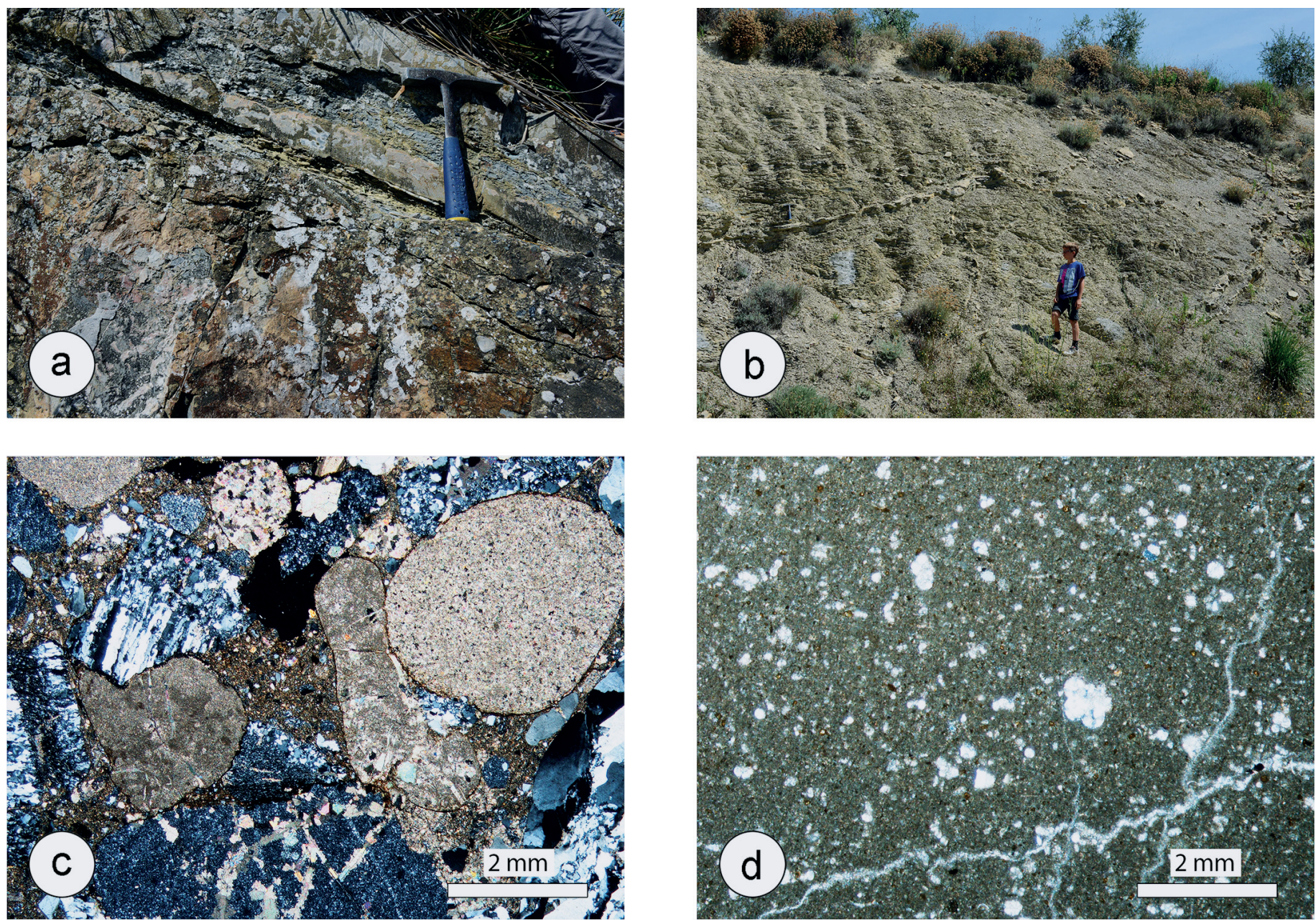

Fig. 8 - Stratigraphic features of the Santa Fiora unit succession: a) Pietraforte Fm. from arenaceous and arenaceous-pelitic lithofacies of PANDELI et alii (2005); $b$ ) outcrop of Santa Fiora Fm; c) Photomicrograph of arenites from the Pietraforte Fm; $d$ ) Photomicrograph of marly limestone from the Santa Fiora Fm.

MutTi (1992), these deposits are characterized by scarce sorting and erosional bottom structures such as small scours and widespread clay chips.

The second lithofacies (arenaceous-conglomeratic lithofacies in PANDELI et alii, 2005) consists of thick to very thick amalgamated beds of coarse- to fine-grained conglomerates that give way abruptly to the overlying coarse-grained sandstones. The clasts are made up of carbonates, radiolarites, and acidic plutonic and metamorphic rocks (e.g. schists and gneisses). Clay chips of pelites are also frequent, especially at the base of the beds.

The upper part of the Pietraforte Fm is characterized by a third lithofacies (pelitic-arenaceous lithofacies in PANDELI et alii, 2005) consisting of medium- to thin-bedded coarse- to fine-grained arenites, siltites and shales with an $\mathrm{a} / \mathrm{p}$ ratio $\cong 1$. These deposits, mainly derived from low-density turbidity currents, are generally characterized by incomplete Tb-e, Tc-e and Tde Bouma sequences. Subordinate thin to medium-thick beds of fine-grained limestones also occur. Levels of Varicoloured Shales are intercalated in the uppermost part of the Pietraforte Fm.

The arenites from the Pietraforte Fm (fig. 8b) are sublitharenites characterized by a mixed siliciclastic-carbonate framework composition. The extrabasinal siliciclastic framework is characterized by mono- and polycrystalline quartz, plagioclase and K-feldspar clasts. Coarse-grained lithic fragments of granitoids are common, whereas porphyritic rhyolites are present in minor amounts. Metamorphic rock fragments include low- to medium-grade schists, micaschists and minor amounts of quartzites, mylonitic quartzites and subordinate gneisses. The quartzite fragments are often characterized by stripped quartz (fig. 8c). No ophiolite-derived rock fragments were detected.

The Santa Fiora Fm (cf. Formazione argilloso-calcarea" of BETTELLI, 1985) consists of carbonate turbidites and minor hemipelagic shales. The carbonate turbidites are represented by medium to very thick beds of limestones and marlstones grading upward to shaly-marlstones and marlyshales. The Tc-e and Td-e Bouma sequences characterize these turbidites. The base of the carbonate turbidites is often characterized by fine to very-fine carbonatic arenites, whereas the main body of these carbonate turbidites is composed of calcilutites and marls with no sedimentary structures (fig. 8d). In thin section these deposits are foraminifera- and radiolaria-bearing wackestones (fig. 8e) in which the matrix is dominated by nannofossils. In the Poggio Nibbio area (SE of Mt. Amiata), lenticular bodies (max 15-20 m thick) of arenaceous beds with a mixed siliciclastic-carbonate framework composition occur as intercalations in the carbonate turbidites. These bodies can be cor- 
Fig. 9 - Stratigraphic distribution of calcareous nannofossil taxa identified in the Santa Fiora Fm.

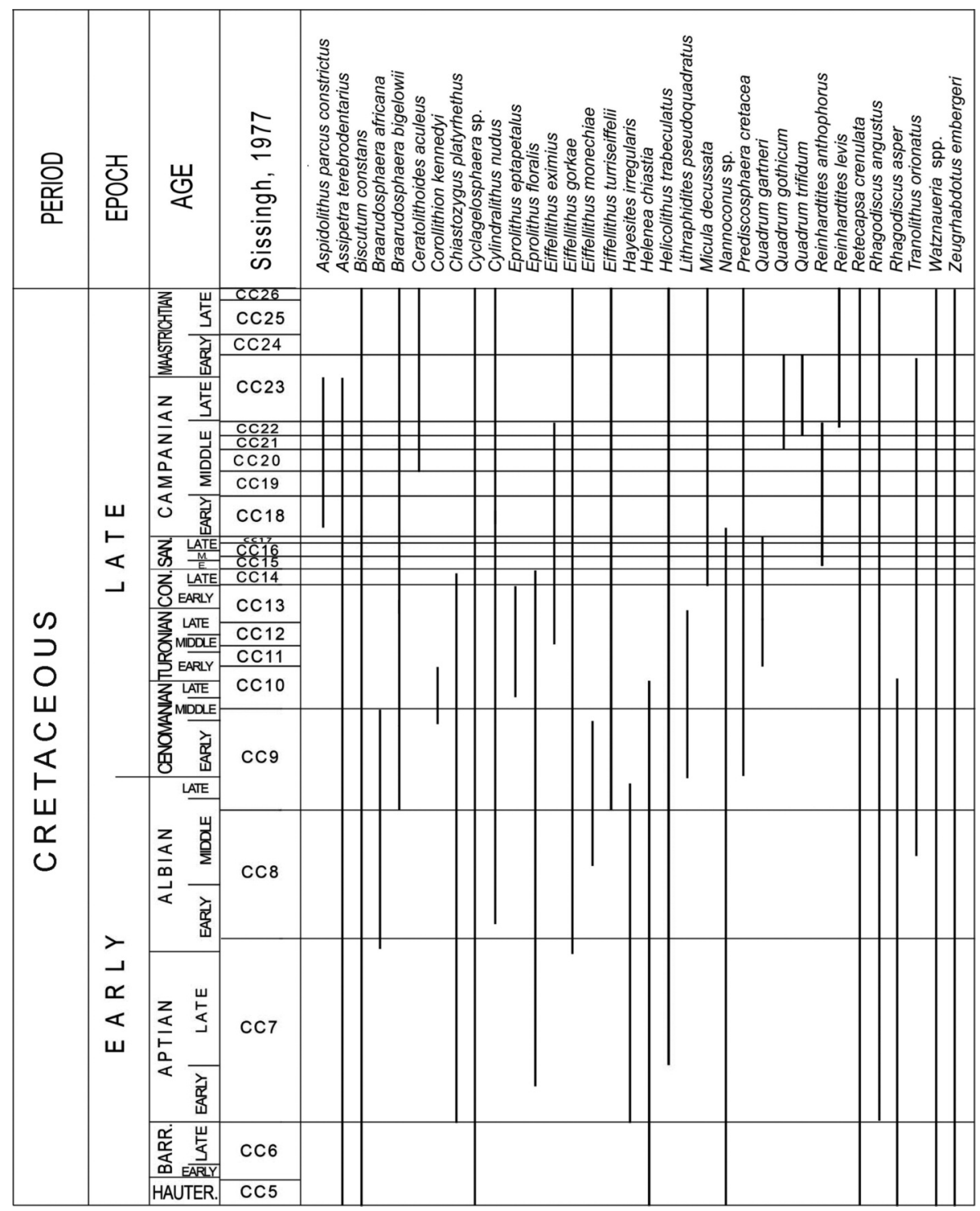

related to the Mt. Rufeno Sandstone Member identified in the Santa Fiora Fm south of Mt. Cetona (Costantini et alii, 1977). According to PANDELI et alii (2005), the composition of these arenites is similar to that of arenites in the Pietraforte Fm. This is likely the result of the heteropy between the Santa Fiora and Pietraforte Fms.

The uppermost stratigraphic level of the Santa Fiora Fm is represented by thin-bedded turbidites consisting of thin to medium beds $(10-60 \mathrm{~cm})$ of fine- to mediumgrained arenites and coarse-grained siltites alternating with 10 to $100 \mathrm{~cm}$-thick beds of shales and shaly marls. These strata are generally well graded only in their uppermost portions, where current ripples and sinusoidal laminae are sometimes present.

In thin section (fig. 8f), the arenites sampled for petrographic analysis show a siliciclastic extrabasinal to mixed (carbonatic/siliciclastic) extrabasinal composition. The framework composition is dominated by monocrystalline quartz, feldspar and extrabasinal carbonate fragments (mudstone made of calcite or dolomite microcrystals). Minor low-grade metamorphic rock fragments and white mica monocrystals are also present. No ophiolite fragments were detected.
The hemipelagic deposits are represented by carbonate-free black shales ranging from $2-3 \mathrm{~cm}$ to $2 \mathrm{~m}$ in thickness.

In addition, basaltic dykes and sills ("Selagiti" Auctt.), up to $2 \mathrm{~m}$ thick and of Early to Late Cretaceous age $(86.3 \pm 1.7 \mathrm{Ma}$ and $97.1 \pm 2.3 \mathrm{Ma}$ radiometric age in BRUNACCI et alii, 1983), occur within the Varicoloured Shales in the area south of Piancastagnaio, in the Senna Valley, and at Bagnolo-Saragiolo, on the southern flank of Mt. Amiata. In the latter area, the most extensive outcrop of these basalts occurs close to Case Lorentano, where there are structures typical of pillow lavas. The dykes and sills are characterized by coarse-grained central portions and very fine-grained contacts with the sedimentary rocks ("chilled margins"). BRUNACCI et alii (1983) defined these magmatic rocks as oceanic intraplate alkali olivine basalts. According to STOPPA et alii (2014), these rocks were derived from the melting of a two-component metasomatized mantle, which can be linked to plume-related magmatism. The emplacement of these magmatic rocks was probably controlled by transform faults that segmented the Ligure-Piemontese oceanic basin in the Cretaceous. 

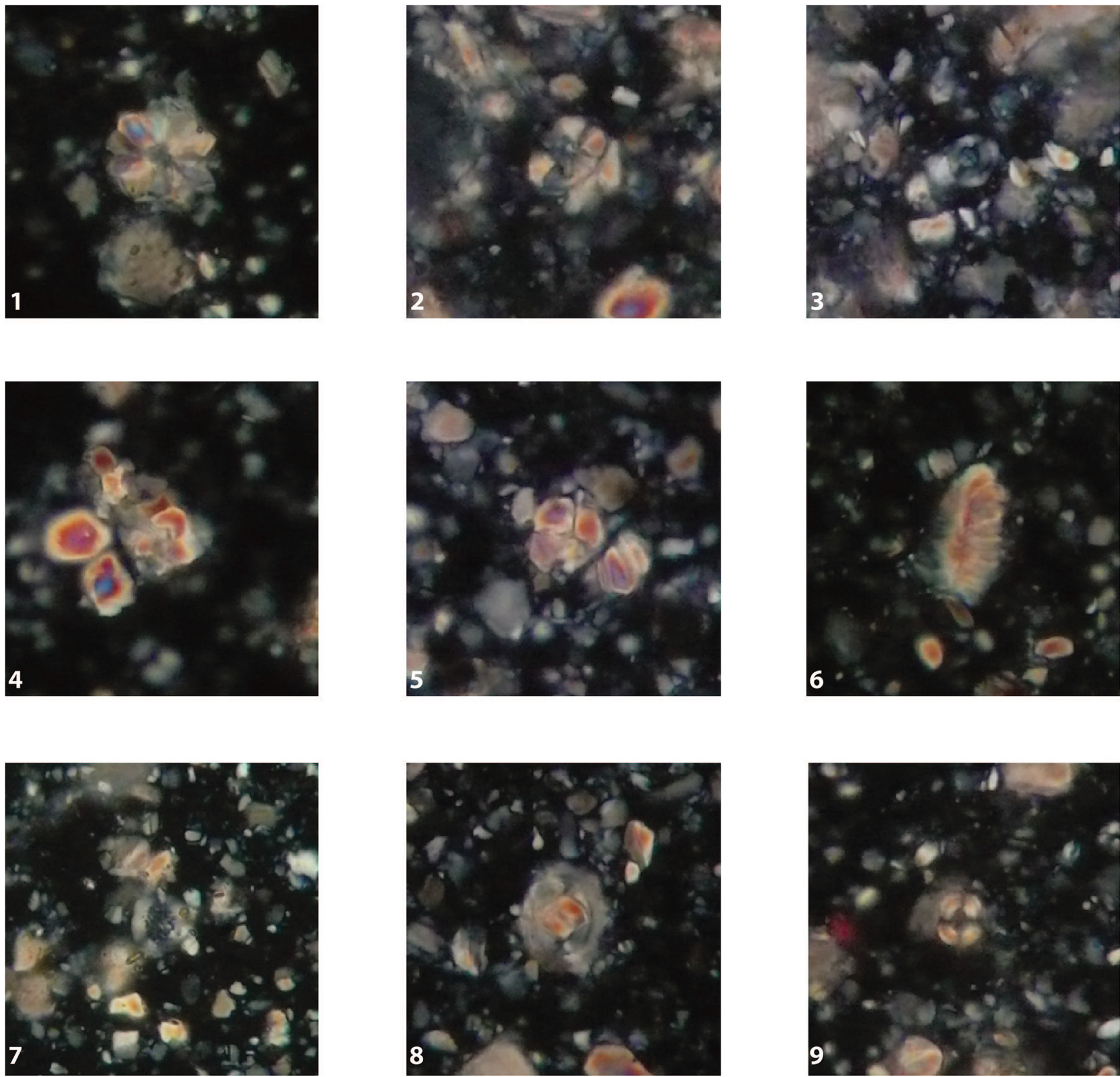

Fig. 10 - Photomicrographs of selected calcareous nannofossils identified in the Santa Fiora Fm. All specimens X1200: 1) Eprolithus floralis, crossed nicols. Sample CDP80; 2) Eiffellithus turriseiffelii, crossed nicols. Sample CDP78; 3) Helenea chiastia, crossed nicols. Sample CDP80; 4) Micula sp., crossed nicols. Sample CDP80; 5) Quadrum gartneri, crossed nicols. Sample CDP68; 6) Nannoconus sp., crossed nicols. Sample CDP78; 7) Retecapsa crenulata, crossed nicols. Sample CDP67; 8) Zeughrabdotus embergeri, crossed nicols. Sample CDP77; 9) Cylindralithus nudus crossed nicols. Sample CDP68.

\section{ii) Paleontological Dating}

PANDELI et alii (2005) suggested a generic Aptian to Maastrichtian age on the basis of the rich foraminiferal microfaunas present in the Santa Fiora Fm; in particular, microfaunas consist of calcareous nannofossil assemblages referable to Aptian Zone CC7 (occurrence of Rhagodiscus angustus + Hayesites irregularis), Albian Zone CC9 (occurrence of Eiffellithus turriseiffelii), late Coniacian-early Santonian Zone CC14 (occurrence of Micula decussata) and Campanian Zones CC18-CC23 (appear- ance of Aspidolithus parcus constrictus, Ceratolithoides aculeus, Quadrum gothicum and Quadrum trifidum). New dating for the recent geological mapping of the Mt. Amiata area partially agrees with these data: the reported assemblages (fig. 9) are referable to late Albian Zone CC9 (occurrence of E. turriseiffelii and Corollithion kennedyi) and to middle-late Campanian Zones CC21-CC22 (occurrence of Q. gothicum, Eiffellithus eximius and Reinhardtites levis). Further data on the Santa Fiora Flysch comes from poorly preserved assemblages (fig. 10a) present in samples collected in the Seggiano and Montegiovi 

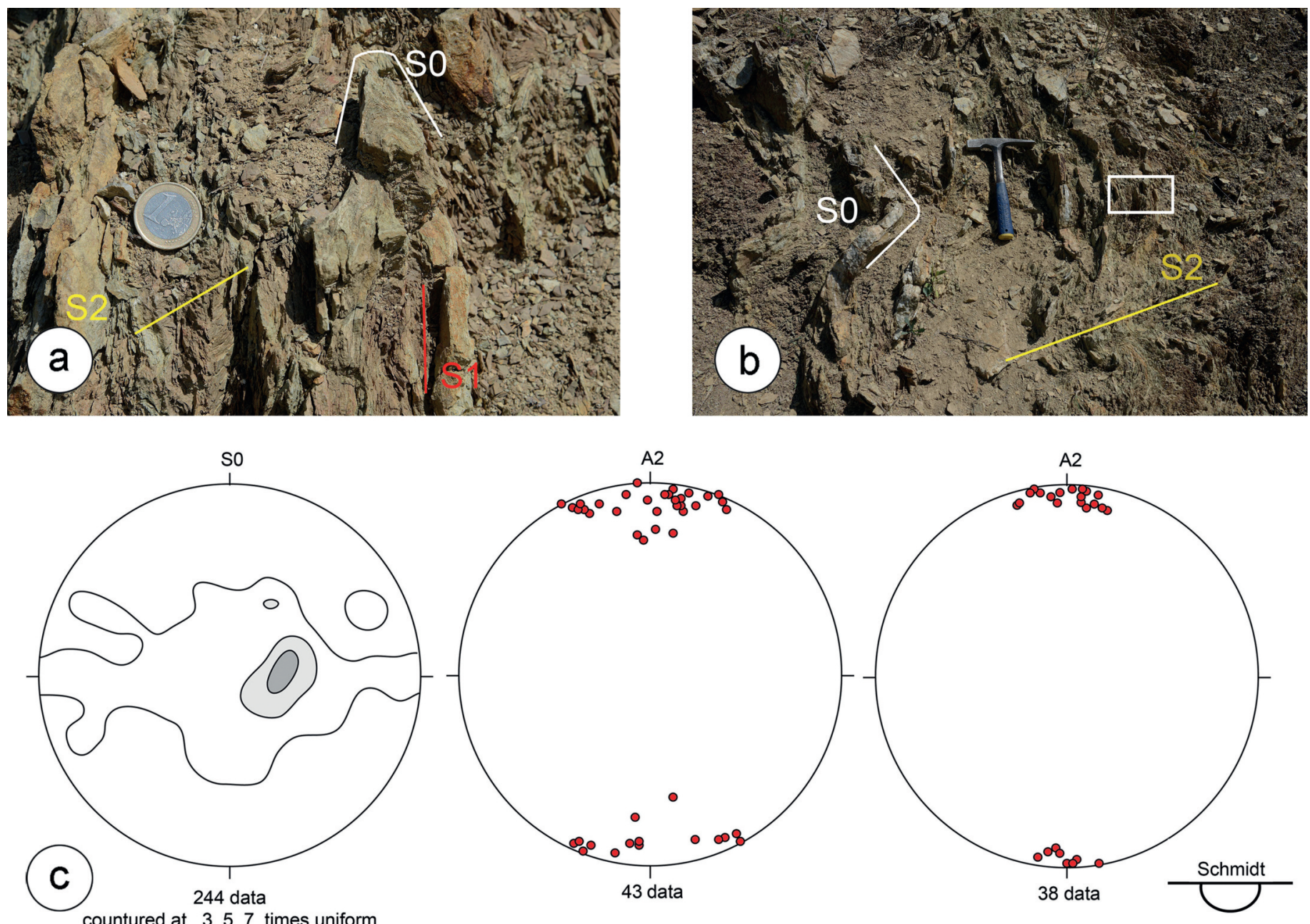

Fig. 11 - Structural features of the Santa Fiora unit: a) F1 folds in the Santa Fiora Fm (S0: bedding; S1: axial plane foliation of F1 fold; S2: axial plane foliation of F2 fold ); $b$ ) F2 meso folds in the Santa Fiora Fm (S0: bedding; S2: axial plane foliation of F2 fold). The boxed area corresponds to $a ; c)$ stereonets of S0, A2 and A3 data from the Santa Fiora unit.

areas on the northern side of Mt. Amiata. The impoverished assemblages have mainly Albian, Turonian and post-Coniacian ages. The late Albian assemblages, which can probably be ascribed to Zone CC9, are represented by E. turriseiffelii, Eiffellithus monechiae, Tranolithus orionatus, Eiffellithus sp., Cylindralithus nudus, Brarudosphaera africana, Eprolithus floralis, Biscutum constans, Chiastozygus platyrhethus, Helenea chiastia, Assipetra terebrodentarius, Helicolithus trabeculatus, Rhagodiscus asper, Retecapsa crenulata, Zeughrabdotus embergeri, Brarudosphaera sp., Cyclagelosphaera sp., Nannoconus spp. and Watznaueria spp. The Turonian is represented by the Lithraphidites pseudoquadratus and Quadrum gartneri species, which occur in assemblages with E. floralis, $R$. crenulata, $T$. orionatus and Watznaueria spp. The late Coniacian-Santonian is represented by assemblages containing Micula decussata, Reinhardtites anthophorus, Eiffellithus gorkae, E. turriseiffelii and Watznaueria spp.

The Pietraforte Fm investigated by PANDELI et alii (2005) contains fossils of generic Late Cretaceous age (small Globigerinidae and Globotruncanidae). The assemblages recovered during recent geological mapping contain poorly preserved taxa ascribed to the late Albian based on the presence of E. turriseiffelii and E. floralis. A few samples collected for this study turned out to be bar- ren or sub-barren, with the very rare specimens of Micula sp., Eprolithus eptapetalus and Watznaueria spp. (fig. 10a) suggesting a middle Coniacian age.

The Varicoloured Shales was referred to the AptianAlbian by PANDELI et alii (2005) due to the presence of varied nannofossil assemblages (i.e. E. turriseiffelii, Prediscosphaera cretacea, Braarudosphaera bigelowii, $H$. irregularis, $R$. angustus, $R$. asper, Nannoconus sp.) in the carbonate beds. The presence of $P$. cretacea and $B$. bigelowii in the early Cenomanian (BURNETT, 1998) indicates that the formation is no older than Cenomanian.

On the whole, paleontological and stratigraphic data suggest that the Pietraforte Fm and the Varicoloured Shales have an ?Aptian to middle Coniacian age, whereas the Santa Fiora Fm seems to span late Coniacian-early Santonian Zone CC14 to middle-late Campanian Zones CC21-CC22.

\section{iii) Deformation History}

The Santa Fiora unit experienced complex deformation in three phases (D1 to D3) mainly identified in the shaly and marly lithotypes of the Pietraforte and Santa Fiora Fms.

The D1 phase is represented by isoclinal to subisoclinal F1 folds with rounded hinges found only in the arenaceous-pelitic facies of the Pietraforte Fm. The F1 folds (fig. 11a) are characterized by an approximately parallel 

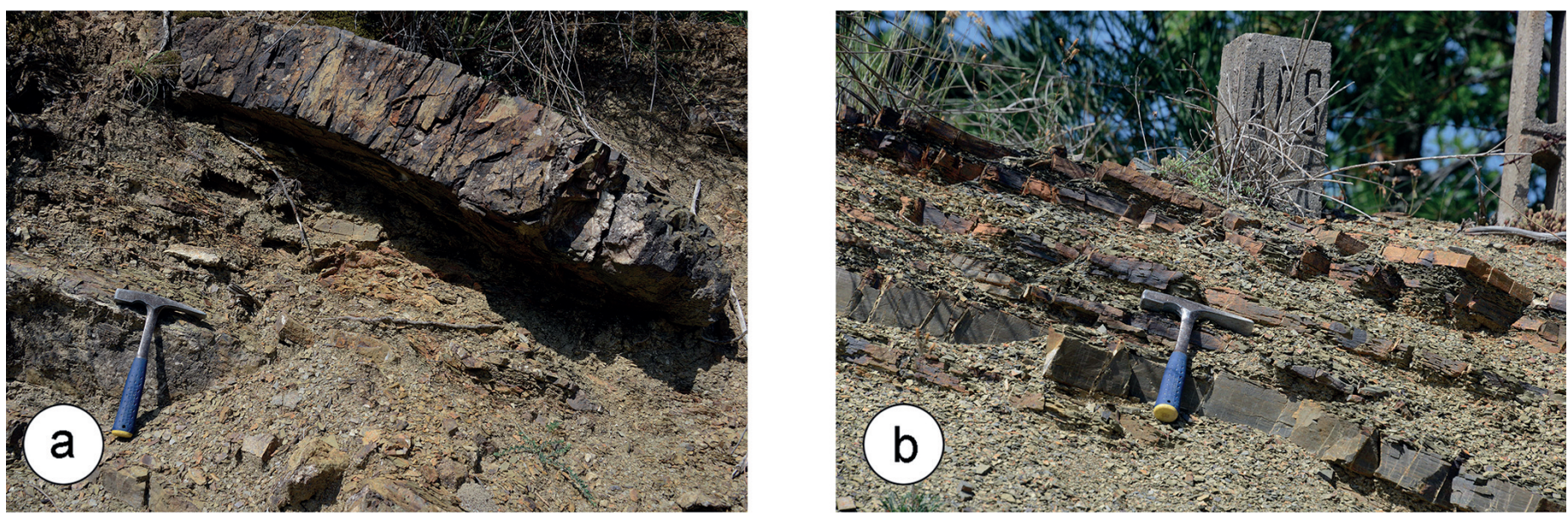

Fig. 12 - Stratigraphic features of the Ophiolitic unit succession: $a$ ) Carbonate turbidites in the Palombini Shale; $b$ ) Siliciclastic turbidites in the Palombini Shale.

geometry (classes 1b, 1c and 2 of RAMSAY, 1967). These folds are not observed in the Santa Fiora Fm, where the D1 phase is represented by cataclastic shear zones parallel to the bedding that are deformed by the subsequent F2 folds. The foliation associated with the F1 folds is represented by disjunctive cleavage.

The structures of the D2 phase are the most widespread and developed best in the Santa Fiora unit. This phase was characterized by the development of asymmetric and overturned F2 folds (fig. 11b) with approximately parallel geometry (classes $1 \mathrm{~b}, 1 \mathrm{c}$ and 2 of RAMSAY, 1967). The hinges of $F 2$ folds range from rounded to subacute, whereas interlimb angles range from $70^{\circ}$ to $140^{\circ}$. The PA2 axial planes are generally low-dipping. On the stereonet, the bearing of A2 fold axes ranges from NW/SE to NE/SW trend (fig. 11c). The trend of the bedding seems to have been mainly acquired during the D2 phase, according to the stereonet in fig. 11c. The S2 axial-plane foliation that developed in both shales and sandstones is a convergent fanning disjunctive cleavage. During the D2 phase the sandstones and arenites of the Pietraforte Fm behaved as a competent layer, whereas the Santa Fiora Fm was folded intensely. The most important thrusts developed during the D2 phase are represented by the floor thrusts of the Santa Fiora unit, which were apparently reworked as low-angle normal faults.

The D3 phase was characterized by the development of asymmetric F3 folds with approximately parallel geometry (classes 1b, 1c and 2 of RAMSAY, 1967). These folds generally trend N/S (fig. 11c) and have subvertical axial planes. Interlimb angles range from $145^{\circ}$ to $80^{\circ}$.

\section{THE OPHIOLITIC UNIT}

The Ophiolitic unit, of which the best outcrops occur at the western edge of the Siena-Radicofani basins, south of the Orcia River and around the Mt. Amiata volcano, mostly consists of Palombini Shale and rare ophiolites, sometimes found at the core of isoclinal folds and/or as slices along the main shear zones. The complex polyphase deformation that affected the Palombini Shale makes it difficult to accurately assess the true thickness of the Ophiolitic unit. The apparent thickness is about 600-700 m.

\section{i) Stratigraphy}

The ophiolites are represented by serpentinites (e.g. south and east of Rocca d'Orcia, northeast of Campiglia d'Orcia, south of Abbadia San Salvatore, south of Santa Fiora and west of Bagno Vignoni) as well as ophicalcites, gabbros, basalts and polymictic ophiolitic breccias, particularly on the southern side of Mt. Amiata.

The Palombini Shale is characterized by carbonate and siliciclastic thin-bedded turbidites alternating with thick-bedded hemipelagic deposits. The carbonate turbidites (fig. 12a) consist of fine-grained silicified limestones (calcilutites and rare, fine calcsiltites) ranging from $10 \mathrm{~cm}$ to about $1.5 \mathrm{~m}$ in thickness. The limestone beds, ranging from $10 \mathrm{~cm}$ to $1.5 \mathrm{~m}$ in thickness, show good lateral continuity. Rare centimetric to decimetric calcarenite layers can be found at the base of the thickest calcilutite beds. The calcilutites are sometimes characterized by structures such as plane laminae, convolute laminae and ripples (cfr. Bouma missing beds, Tb-e, Tc-e or F9a facies of MutTI, 1992) that allow us to ascribe these deposits to low-density turbidity currents. The thickest beds show a Te Bouma interval consisting of marlstones and marly shales, which were sampled for nannoplankton analysis. South of Santa Fiora, the Palombini Shale is represented by a thick level, whereas the carbonate turbidites are represented by m-thick beds of marlstones and marly shales (BRUNACCI et alii, 1983).

In places (e.g. south of Saragiolo, SE side of Mt. Amiata), thin-bedded siliciclastic turbidite beds are intercalated within the shales; these beds consist of quartz-rich arenites ranging in grain size from medium-fine sand to siltstone.

The carbonate and the siliciclastic thin-bedded turbidites (fig. 12b) both alternate with thick-bedded carbonate-free shales up to 3-4 $\mathrm{m}$ in thickness. These deposits represent hemipelagic background sedimentation.

The Palombini Shale can be divided into two different members; the lowermost one is characterized by prevailing carbonate turbidites, the uppermost one by siliciclastic turbidites and hemipelagic shales. 


\section{ii) Paleontological Dating}

The Palombini Shale of Southern Tuscany is ascribed to the uppermost Early Cretaceous (MARCUCCI \& PASSERINI, 1980, 1982). Samples collected recently to create the 1:50.000 "Castel del Piano" geological map yielded assemblages of rare, poorly preserved calcareous nannofossils that can be referred to late Hauterivian-Barremian Zones CC5-CC6 of SISSINGH (1977) due to the presence of Assipetra terebrodentarius and Nannoconus steinmannii, as well as Watznaueria spp., Nannoconus colomii, Zeugrhabdotus embergeri and Lithraphidites carniolensis (fig. 13). The occurrence of Eprolithus floralis extends the age of the Palombini Shale cropping out in this area to Aptian Zone CC7 (fig. 14).

\section{iii) Deformation History}

The complex structural history of the Palombini Shale involved four distinct deformation phases (hereafter referred to as D1, D2, D3 and D4).

Prior to deformation, calcite veins ranging from $1-2 \mathrm{~mm}$ to $5-6 \mathrm{~cm}$ in thickness formed parallel to the bedding of the Palombini Shale. These veins are characterized by a mosaic texture, with calcite grains enclosing fragments of the vein walls.

The D1 phase is mainly represented by a well-developed, continuous S1 foliation generally parallel to or at low angle to the bedding surfaces. The $\mathrm{S} 1$ foliation is associated with non-cylindrical, tight to isoclinal folds showing subrounded and thickened hinge zones. The F1 folds are characterized by a roughly similar geometry (classes 1c, 2 and 3 of RAMSAY, 1967). The stereographic distribution of A1 fold axes (fig. 15c) is scattered due to the presence of non-cylindrical folds. Brittle boudinage of the fold limbs and associated necking are very common features producing a fabric in which isolated fragments of beds are scattered in the shaly matrix.

In thin section, the S1 axial-plane foliation of shales can be classified as poorly developed slaty cleavage (fig. 15a): aligned phyllosilicates and elongate quartzalbite-mica aggregates show the effects of deformation, mainly consisting of pressure-solution parallel to the slaty cleavage domains. The $\mathrm{S} 1$ foliation is characterized by quartz + calcite + albite + chlorite + white mica + Fe-oxide recrystallization. Extension veins, with infilling of calcite fibres perpendicular to the vein walls, developed during D1 deformation. In thin section, the antitaxial calcite fibres are characterized by the widespread presence of a median line and inclusion bands of wall rock fragments related to crack-seal deformation (RAMSAY, 1980). According to the classification of twinning in thin section (BURKHARD, 1993), calcite from antitaxial veins shows type I and II twins. The type of calcite twins (fig. 15b) and data on illite crystallinity (FRANCESCHELLI et alii, 1994) suggest a $\mathrm{T}$ between $150^{\circ}$ and $200^{\circ} \mathrm{C}$ and $\mathrm{P}$ lower than 3 Kbars.

Asymmetric and overturned folds with approximately parallel geometry (classes 1b, 1c and 2 of RAMSAY, 1967) developed during the D2 phase. The hinges of F2 folds range from rounded to acute, whereas the interlimb angles range from $70^{\circ}$ to $140^{\circ}$. The axial planes dip at low angles. On the stereonet, the A2 fold axes trend from NNW/SSE to NNE/SSW (fig. 15c), as also suggested by the dispersion of the bedding (fig. 15c). The S2 axial-

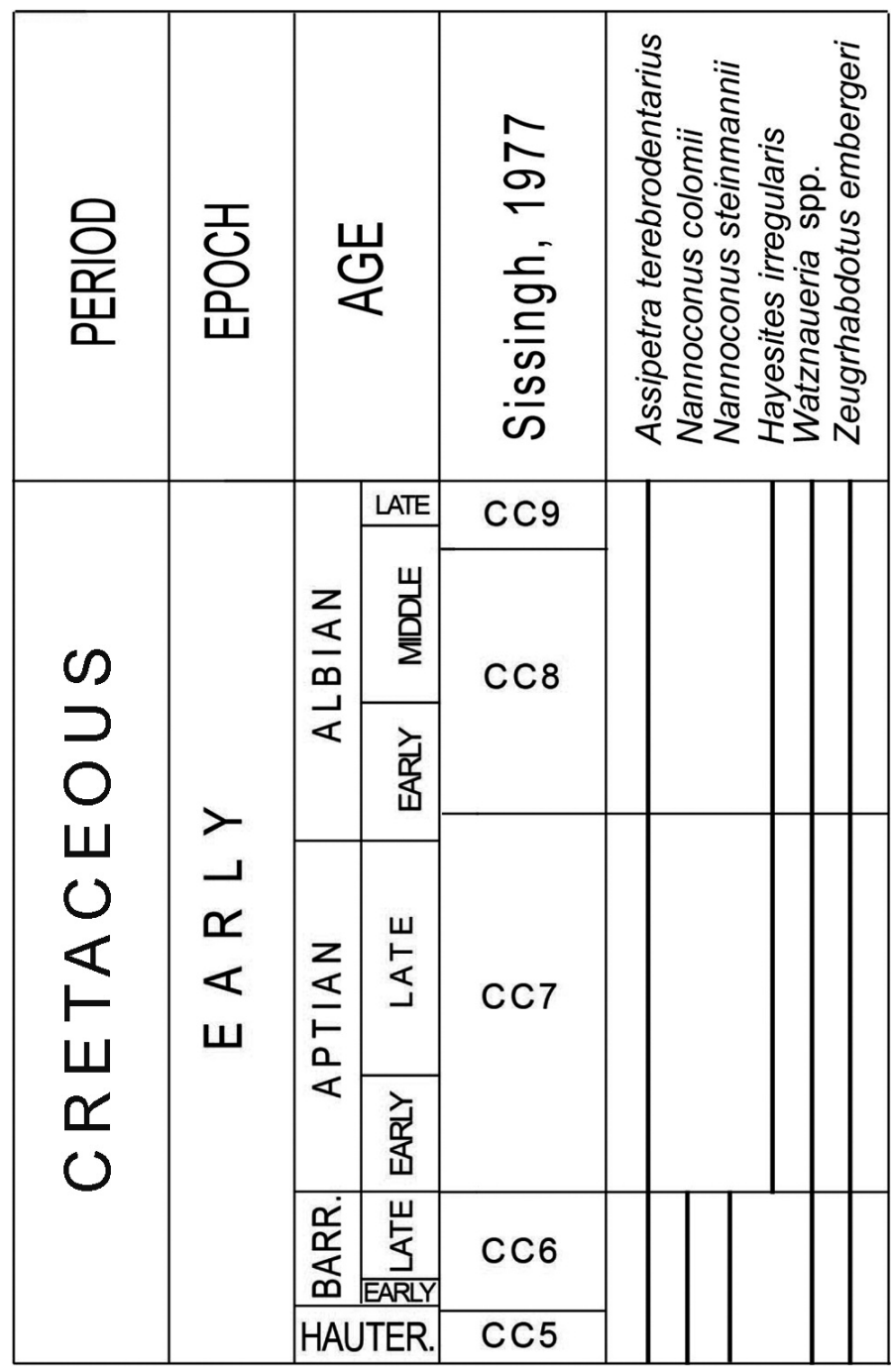

Fig. 13 - Stratigraphic distribution of calcareous nannofossil taxa identified in the Palombini Shale.

plane foliation developed in the shales can be considered a zonal-type convergent-fanning crenulation cleavage, with parallel domains showing discrete transitions. Crenulation cleavage is present in the shales, whereas it is absent or poorly developed in limestones and sandstones. The F2 folds are closely associated with low-angle shear zones marked by foliated cataclasites with S-C structures.

Thrusts marked by foliated cataclasites with S-C structures developed during the D3 phase. Kinematic criteria inferred from these foliated cataclasites indicate a top-to-the east sense of shear. The cataclasites are up to several meters thick, producing a block-in-matrix fabric that characterizes large volumes of the Palombini Shale.

Gentle folds with approximately parallel geometry (classes 1b, 1c and 2 of RAMSAY, 1967) developed during the D4 phase. Interlimb angles range from $90^{\circ}$ to $160^{\circ}$, whereas axial planes are always subverticalii On the stereonet, the A4 fold trend N-S, producing a dispersion clearly detected in the stereonets of fig. 15c. The F4 folds are characterized by a well-spaced, subvertical fracture cleavage. 

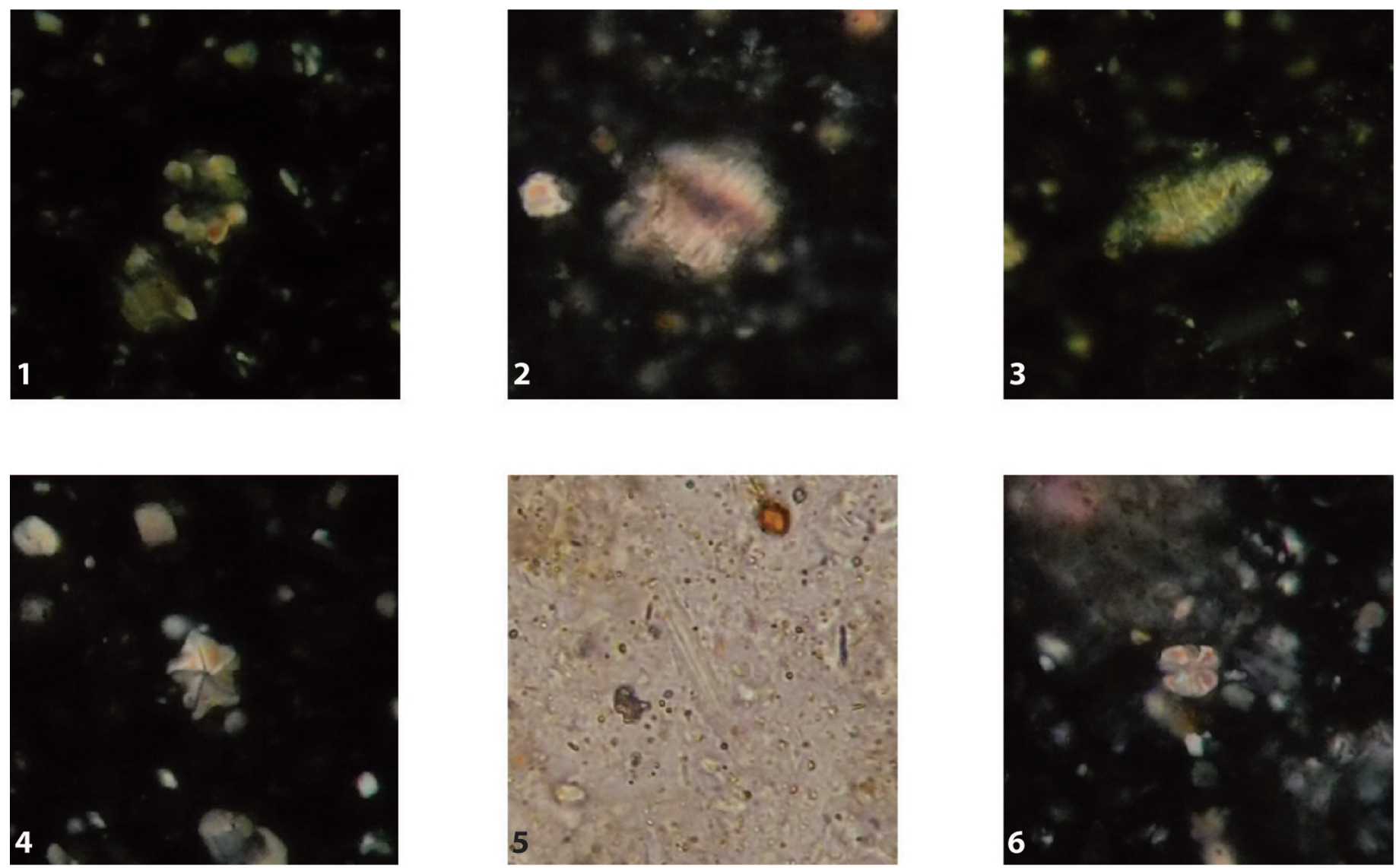

Fig. 14 - Photomicrographs of selected calcareous nannofossils identified in the Palombini Shale. All specimens X1200: 1) Eprolithus floralis, crossed nicols. Sample CDP93; 2) Nannoconus colomii, crossed nicols. Sample CDP94; 3) Nannoconus steinmannii, crossed nicols. Sample CDP94; 4) Michrantolithus obtusus, crossed nicols. Sample CDP92; 5) Lithraphidites carniolensis, parallel light. Sample CDP92; 6) Assipetra terebrodentarius, crossed nicols. Sample CDP91.

\section{CORRELATION WITH THE SUB-LIGURIAN AND LIGURIAN UNITS OF THE NORTHERN APENNINES}

The collected stratigraphic and paleontogical data can be used to correlate the Ligurian and Sub-Ligurian units of the Mt. Amiata area with those cropping out in Southern Tuscany and in the Ligurian-Emilian Apennines.

Stratigraphic and paleontological data confirm the correlation between the Canetolo unit cropping out in the Mt. Amiata area and the same unit in the Emilian Apennines. The review of paleontological data on the Canetolo unit of the Emilian Apennines (PERILLI et alii, 2009), derived from the semiquantitative analysis of nannofossil assemblages, suggests an early Eocene (NP11) to middle Eocene (NP14) age for the Calcari di Groppo del Vescovo Fm (= Vico Fm) and a late Paleocene (NP5) to middle Eocene (NP14 to NP15) age for the Argille e Calcari Fm. These ages agree well with the middle Eocene age (NP15) of the Argille e Calcari Fm in the Mt. Amiata area. In addition, the heteropic relationship between the Argille e Calcari Fm and the Vico Fm agrees with the stratigraphic setting in the Emilian Apennines (PERILLI et alii, 2009 and references therein). However, the lack of Paleoceneearly Eocene deposits and the reduced thickness of the succession in the Mt. Amiata area indicate that the Canetolo unit was strongly affected by tectonic delamination.

Data on the Ophiolitic unit reveals the presence of a succession consisting of Palombini Shale with rare out- crops of ophiolites at the core of isoclinal folds and/or along the main shear zones. The Ophiolitic unit can be correlated with the Bracco-Val Graveglia unit from the Ligurian-Emilian Apennines (e.g. CoRTESOGNO et alii, 1987) and the Upper Ophiolitic unit (e.g. BERTINI et alii, 2000) of Southern Tuscany. According to the literature (PERILLI, 1997), the age of Palombini Shale cropping out in Southern Tuscany ranges from early Valanginian to late Hauterivian/early Barremian. BERTINI et alii (2000) indicate an Aptian age for the top of the Palombini Shale, whereas the uppermost levels of this formation in the Ligurian-Emilian Apennines have been referred to the Santonian (MARroni \& PERILli, 1990). These data are coherent with data on the Palombini Shale in the Mt. Amiata area indicating a late Hauterivian-early Barremian age. It follows that the succession of the Ophiolitic unit in the Mt. Amiata area is more delaminated than in other areas of the Northern Apennines.

It is more difficult to correlate the Santa Fiora unit with the Ligurian units of Southern Tuscany and the Ligurian-Emilian Apennines.

This unit can be regarded as belonging to the External Ligurian units, as suggested by the presence of carbonate turbidites of Late Cretaceous age ("Helminthoid Flysch"). In the geological framework of Southern Tuscany, the lack of ophiolite-bearing clastic deposits and the Late Cretaceous age of the carbonate turbidites suggest a correlation between the Santa Fiora unit and the Monteverdi 

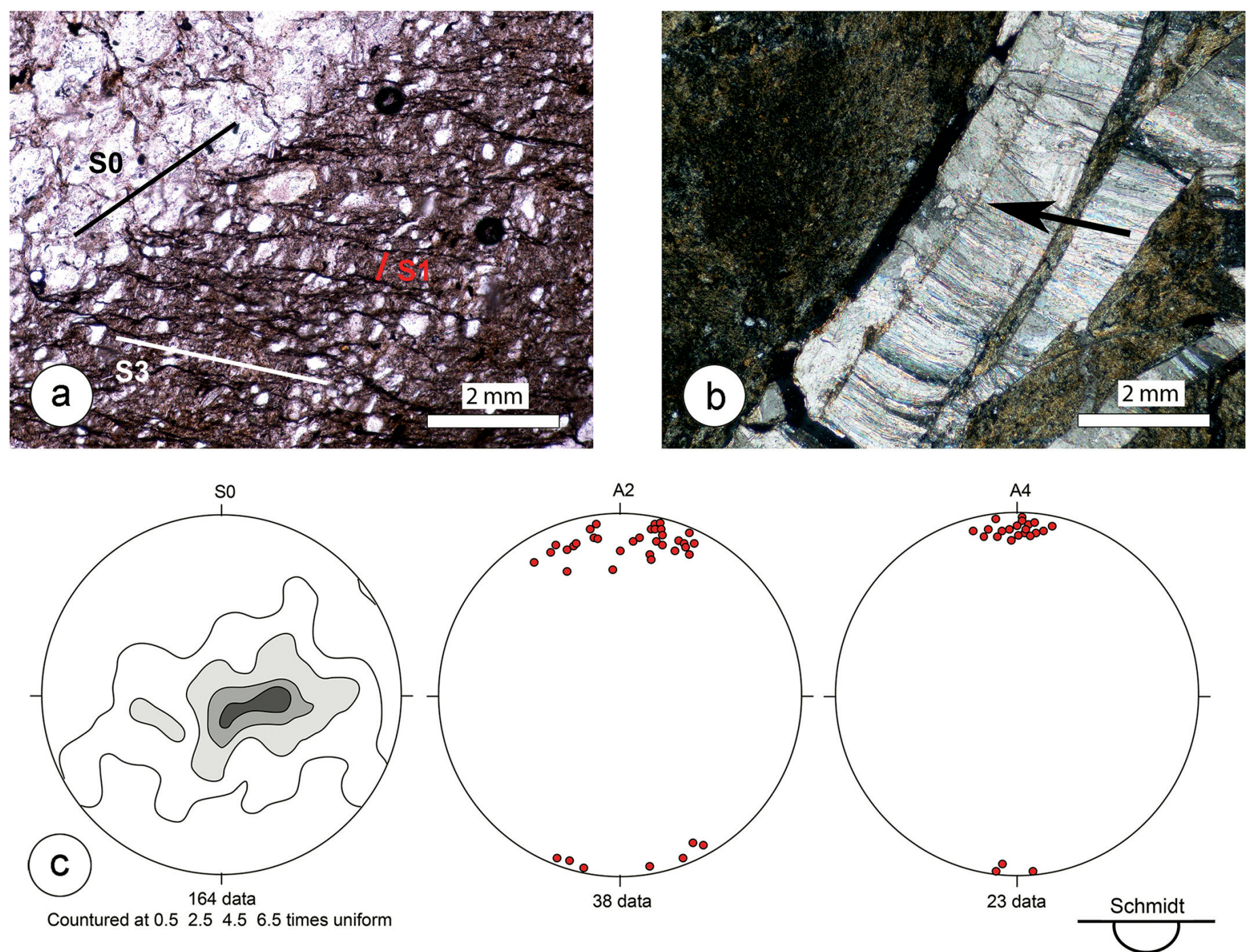

Fig. 15 - Structural features of the Ophiolitic unit: a) Photomicrograph of the relationship between S0, S1 and S3 (S0: bedding; S1: S1 foliation; S2: S2 foliation); b) Photomicrograph of antitaxial calcite vein (arrow indicates the median line); $c$ ) stereonets of S0, A2 and A4 data from the Ophiolitic unit.

Marittimo unit (e.g. LAZZAROTTO et alii, 2002 and references therein). The latter unit crops out in areas north of Mt. Amiata and is represented by the Argilliti e Calcari di Poggio Rocchino Fm, which consists of varicoloured shales with scattered intercalations of a few limestone and marl beds showing late Albian-early Turonian nannofossil assemblages (MARINO \& MONECHI, 1994; LAZZAROTTO et alii, 2002). This formation, which can be correlated with the Varicoloured Shales of the Santa Fiora unit, shows gradual stratigraphic relationships with the Monteverdi Marittimo Fm, a Helminthoid Flysch of Santonian-Maastrichtian age (MARINO \& MONECHI, 1994). As in the case of the Santa Fiora unit, the entire succession of the Monteverdi Marittimo unit is devoid of ophiolitebearing clastic deposits.

As for the Emilian Apennines, the presence of the Pietraforte Fm, i.e. a thick succession of arenites and conglomerates characterized by a mixed siliciclastic-carbonate framework composition (FONTANA \& MANTOVANI UGUZZONI, 1987; FONTANA, 1991), suggests a close correlation between the Santa Fiora unit and the succession of the Monte Cassio unit belonging to the Eastern External Ligurian units (MARRONI et alii, 2001 and references therein). The succession of the Monte Cassio unit consists of Palombini Shale (Early Cretaceous), Ostia Sandstone and Varicoloured Shales (Cenomanian-late Campanian), which give way to Campanian-Maastrichtian carbonate turbidites (Monte Cassio Helminthoid Flysch). The varicoloured, hemipelagic shales are characterized by intercalations of the Salti del Diavolo Conglomerate. Both the arenites and the conglomerate are characterized by a mixed siliciclastic-carbonate framework composition (BRACCIALI et alii, 2007 and references therein).

The framework composition of the Pietraforte arenites, characterized by siliciclastic extrabasinal to mixed (carbonatic/siliciclastic) extrabasinal arenites, is comparable to the composition of the lowermost part of the Cassio unit sequence (cfr. Ostia Sandstone, Scabiazza Sandstone, Salti del Diavolo Conglomerate and Case Baruzzo Sandstone; Bracciali et alii, 2007; VESCOVI et alii, 1999; DANIELE \& BIANCHI, 1995) and suggests a similar source area.

On the whole, the complete succession of the Cassio unit is characterized by deposits derived from a continental margin devoid of ophiolites (VALLONI \& ZUFFA, 1984). The correlation between the Cassio Flysch and the Santa 
Fiora Fm suggests that the base of the latter formation is middle-late Campanian (Zones CC21-CC22) and that the old nannofossil assemblages are reworked. However, more data is required to confirm this hypothesis, because it is impossible to exclude that the base of the Santa Fiora Fm is older than that of the Cassio Flysch. Note that at the map scale the Santa Fiora unit forms a synformal structure with the Santa Fiora Fm at the core, as in several External Ligurian units of the Northern Apennines (e.g. MARRONI et alii, 2002).

When comparing the pile of tectonic units identified in the Mt. Amiata area with that reconstructed in Southern Tuscany and the Ligurian-Emilian Apennines, the most striking difference is the lack of several tectonic units and the strong reduction in the thickness of the outcropping units. For instance, the Montaione unit cropping out in Southern Tuscany is missing in the Mt. Amiata area. This unit consists of carbonate turbidites of Campanian-Maastrichtian age (Helminthoid Flysch) with a base consisting of ophiolite-bearing deposits such as pebbly mudstones, pebbly sandstones and coarse-grained arenites. In addition, the Canetolo unit and the Ophiolitic unit are both represented by very thin successions. This setting can be considered the result of low-angle normal faulting during middle Miocene extensional tectonics, which produced a strong delamination of the tectonic stack originated during the earlier compressive evolution of the Apennine belt. This picture is coherent with the occurrence of either Palombini Shale or the Santa Fiora Fm directly above the lowermost levels of the Tuscan Nappe (e.g. Palombini Shale over the Triassic Fms of the Tuscan Nappe; BROGI, 2004c; PANDELI et alii, 2005).

Structural analyses indicate that the Ligurian and Sub-Ligurian units experienced complex polyphase deformation involving several fold phases. It is difficult to establish a correlation among these phases in the different units because their boundaries are represented by low-angle normal faults developed during middle Miocene extensional tectonics. These shear zones are deformed by open folds with subvertical axial planes and $\mathrm{km}$-long wavelengths that developed during the D3 phase in the Santa Fiora and Canetolo units and the D4 phase in the Ophiolitic unit. The folds are likely linked to megaboudinage of the Tuscan Nappe during extensional tectonics (BROGI, 2004b). A couple of low-angle normal faults with the same dip but with a staircase trajectory produced a megaboudin delimited at the top and bottom by two extensional shear zones. One side of the megaboudin was thus forced to rotate passively, producing a morphology characterized by two steep sides with opposite dip. The overlying Ligurian and Sub-Ligurian units were thus folded to adapt to the shape of the underlying megaboundins.

The pre-D4 and pre-D3 phase deformations identified in the Ophiolitic unit and in the Santa Fiora and Canetolo units, respectively, can be referred to the pre-middle Miocene.

The more complex deformation history detected in the Ophiolitic unit can be ascribed to intraoceanic convergence and subsequent continental collision during the Late Cretaceous-middle Eocene (MARRONI et alii, 2010). As in the case of the Internal Ligurian units of the Ligurian-Emilian Apennines (MARronI, 1991; MARRONI et alii, 2004; MENEGHINI et alii, 2007), D1 and D2 deformation identified in the Ophiolitic unit can be ascribed to deformation in the accretionary wedge of the Ligure-Piemontese basin. This is because the anchizone metamorphism (FRANCESCHELLI et alii, 1994) associated with the D1 phase developed before the thrusting of the Ophiolitic unit over the External Ligurian and SubLigurian units.

As for the D1 and D2 phases identified in the Canetolo and Santa Fiora units, deformation was likely achieved during the closure of the Ligure-Piemontese basin and the subsequent onset of continental collision.

\section{CONCLUSIONS}

The data collected indicate that the stratigraphic setting of the Ligurian and Sub-Ligurian units in the Mt. Amiata area was strongly reworked by middle Miocene extensional tectonics. Although all the successions were strongly delaminated during this phase, detailed structural and stratigraphic analyses performed in the context of the Regional Geological Mapping project, integrated with data from the literature, were used to identify the main features of these units.

The Sub-Ligurian units are represented by the Canetolo unit, a succession consisting of the Argille e Calcari and Vico Fms of middle Eocene (Zone NP15) age. The Santa Fiora unit consists of the Pietraforte Fm and Varicoloured Shales topped by the Santa Fiora Fm. The Pietraforte Fm shows heteropic relationships with the Varicoloured Shale, and both formations can be referred to the ?Aptian to middle Coniacian, whereas the age of the Santa Fiora Fm seems to span from late Coniacianearly Santonian (Zone CC14) to the middle-late Campanian (Zones CC21-CC22). The Ophiolitic unit is represented by scattered Middle-Late Jurassic ophiolites associated with Palombini Shale spanning from late Hauterivian-early Barremian Zone CC5 to early Aptian Zone CC7 of SissingH (1977).

Structural data indicates that all the Ligurian and Sub-Ligurian units were affected by complex polyphase deformation with no metamorphic imprint (medium to high diagenetic conditions for the Canetolo and Santa Fiora units) or very low-grade metamorphism (anchizone for the Ophiolitic unit). This deformation occurred during the closure of the Ligure-Piemontese oceanic basin and the subsequent continental collision, which predates the middle Miocene extensional tectonics.

These features are comparable to those described in the literature on the Ligurian and Sub-Ligurian units cropping out in Southern Tuscany and the Ligurian Apennines. In particular, the Santa Fiora and Ophiolitic units can be correlated with, respectively, the Monteverdi Marittimo and Upper Ophiolitic units cropping out in Southern Tuscany. As for the Ligurian-Emilian Apennines, the same units can be correlated with, respectively, the Cassio and Bracco-Val Graveglia units. These correlations indicate that the Ligurian and Sub-Ligurian units have good continuity, showing quite homogeneous features across the whole Apennine belt.

\section{ACKNOWLEDGMENTS}

The research has been funded by CNR-IGG and by University of Pisa (Fondi Ateneo). We are grateful to Andrea Festa and Hazim Hratovic whose advices contributed to improve the paper. 


\section{REFERENCES}

Abbate E., Bortolotti V., Conti M., Marcucci M., Passerini P., PrincIPI G. \& TREves B. (1986) - Apennines and Alps Ophiolites and the evolution of the Westhern Tethys. Mem. Soc. Geol. It., 31, 23-44.

Ambrosetti P., Carboni M.G., Conti M.A., Costantini A., Esu D., Gandin A., Girotti O., Lazzarotto A., Mazzanti R., Nicosia V., PARISI G. \& SANDRElli F. (1978) - Evoluzione paleogeografica e tettonica nei bacini Tosco-Umbro-Laziali nel Pliocene inferiore. Mem. Soc. Geol. It., 19, 573-580.

Aruta G., Bruni P., Cipriani N. \& Pandeli E. (1998) - The siliciclastic turbidite sequences of the Tuscan Domain in the Val di Chiana-Val Tiberina area (eastern Tuscany and north-western Umbria). Mem. Soc. Geol. It., 52, 579-593.

Barchi M.R., Landuzzi L., Minelli A. \& Pialli G. (2001) - Outer Northern Apennines. In: Vai G.B. \& Martini I.P. (eds.), Anatomy of an Orogen: the Apennines and Adjacent Mediterranean Basin, Kluwer Academic Publishers, 215-254.

Batini F., Brogi A., Lazzarotto A., Liotta D. \& Pandeli E. (2003) Geological features of the Larderello-Travale and Mt. Amiata geothermal areas (southern Tuscany, Italy). Episodes, 26 (3), 239-244.

Bertini G., Costantini A., Cameli G.M., Di Filippo M., DecanDia F.A., Elter M.F., Lazzarotto A., Liotta D., Pandeli E., SANDRElli F. \& TORO B. (1991) - Struttura geologica dai Monti di Campiglia a Rapolano Terme (Toscana Meridionale): stato delle conoscenze e problematiche. Studi Geologici Camerti, Vol. Spec., 1, 155-178.

Bertini G., Cornamusini G., Lazzarotto A. \& Maccantelli M. (2000) - Stratigraphic and tectonic framework of the Ligurian Units in the Castellina M.ma Hills (Southern Tuscany, Italy). Boll. Soc. Geol. It., 119, 687-701.

BetTELLI G. (1980) - Le unità tettoniche del complesso ligure fra il fiume Albegna e il fiume Fiora (Toscana Meridionale). Mem. Soc. Geol. It., 21, 157-161.

Bettelli G. (1985) - Geologia delle alti valli dei fiumi Albegna e Fiora (Toscana Meridionale). Geol. Romana, 24, 147-188.

Bettelli G., BonAzzi U. \& FAzZinI P. (1980) - Il complesso alloctono ligure nella Toscana meridionale. Mem. Soc. Geol. It., 21, 163-168.

BocCALETTI M. \& SANI F. (1998) - Cover thrust reactivations related to internal basement involvement durino Neogene-Quaternary evolution of the northern Apennines. Tectonics, 17, 112-130.

BONINI M. \& SANI F. (2002) - Extension and compression in the Northern Apennines (Italy) interland: Evidences from the Late Miocene-Pliocene Siena-Radicofani Basin and relation with basement structures. Tectonics, 21, 1-28.

Bortolotti V., PAsserini P., SAgri M. \& Sestini G. (1970) - The Miogeosynclinal Sequences. In: G. Sestini (ed.), Development of the Northern Apennines geosyncline. Sedim. Geol., 4, 341-444.

Bortolotti V., Principi G. \& Treves B. (1990) - Mesozoic evolution of the western Tethys and the Europe/Iberia/Adria plate junction. Mem. Soc. Geol. It., 45, 393-407.

Bown P.R. \& Young J.R. (1998) - Introduction. In: P.R. Bown (ed.) Calcareous Nannofossil Biostratigraphy. Micropal. Soc. Publ. Series, 7, 314 pp.

Bracciali L., Marroni M., Pandolfi L. \& Rocchi S. (2007) - Petrography and geochemestry of western Thethys Mesozoic sedimentary covers (Alpine Corsica and Northern Apennines): a valuable tools in constraining sediments provenance and margin configuration. In Arribas J., Critelli S. \& Jhonsson M.J. (eds.), Sedimentary Provenence and Petrogenesis: perspectives from Petrography and Geochemistry. Geol. Soc. of Amer. Special Paper, 420, 73-93.

Brogi A. (2004a) - Assetto geologico del nucleo di Falda Toscana affiorante nel settore occidentale del Monte Amiata (Appennino Settentrionale): strutture pre-e sincollisionali relitte preservate durante lo sviluppo della tettonica distensiva post-collisionale. Boll. Soc. Geol. It., 123, 444-461.

BRogi A. (2004b) - Miocene low-angle detachments and upper crust megaboudinage in the Monte Amiata geothermal area (Northern Apennines, Italy). Geodin. Acta, 17, 375-387.

Brogi A. (2004c) - Miocene extension in the inner Northern Apennines: the Tuscan Nappe megaboudins in the Mt. Amiata geother- mal area and their influence on Neogene sedimentation. Boll. Soc. Geol. It., 123, 513- 529.

Brogi A. \& FABBrini L. (2009) - Extensional and strike-slip tectonics across the Monte Amiata-Monte Cetona transect (Northern Apennines, Italy) and seismotectonic implications. Tectonophysics, 476, 195-209.

Brogi A. \& Lazzarotto A. (2002) - Deformazioni sin-collisionali nella Falda Toscana a SW del Monte Amiata (Toscana meridionale): il sovrascorrimento del Monte Aquilaia. Boll. Soc. Geol. It., 121, 299-312.

Brunacci S., Donati C., Faraone D., Manganelli V. \& Stoppa F. (1983) - Vulcanismo alcalino cretaceo post-ofiolitico nell'alloctono liguride della Toscana Meridionale. I. L'area del T. Senna (Siena-Grosseto). Ofioliti, 8, 47-76.

BURKHARD M. (1993) - Calcite twins, their geometry, appearance, and significance as stressstrain markers and indicators of tectonic regime: a review. Journ. Struct. Geol., 15, 351-368.

Burnett J.A. (1998) - Upper Cretaceous. In: Bown P.R (ed.), Calcareous Nannofossil Biostratigraphy. Chapman \& Hall, Kluwer Academic, London, 225-265.

Calamai A., Cataldi R., Souarci P. \& Taffi (1970) - Geology, geophysics and hydrogeology of the Monte Amiata geothermal field. Geothermics, 1, 1-9.

CARMignani L. \& KLIGField R. (1990) - Crustal extension in the northern Apennines: the transition from compression to extension in the Alpi Apuane core complex. Tectonics, 9, 1275-1303.

Carmignani L., Decandia F.A., Disperati L., Fantozzi L., LazzaRotto A., Liotta D. \& Oggiano G. (1995) - Relationships between the Tertiary structural evolution of the Sardinia-CorsicaProvençal Domain and the Northern Apennines. Terra Nova, 7, 128-137.

Carmignani L., Decandia F.A., Disperati L., Fantozzi L., KligField R., Lazzarotto A., Liotta D. \& Meccheri M. (2001) Inner Northern Apennines. In: G.B. Vai \& I.P. Martini (eds.), Anatomy of an orogen: the Apennines and adjacent Mediterranean basins,. Kluwer Academic Publishers, Dordrecht/Boston/ London, 197-214.

Cortesogno L., Galbiati B. \& Principi G. (1987) - Note alla "Carta geologica delle ofioliti del Bracco" e ricostruzione della paleogeografia Giurassico-Cretacica. Ofioliti, 12, 261-342.

Costa E., Pialli G. \& Plesi G. (1998) - Foreland basins of the Northern Apennines: relationships with passive subduction of the Adriatic lithosphere. Mem. Soc. Geol. It., 52, 595-606.

Costantini A., Lazzarotto A. \& Micheluccini M. (1977) - Le formazioni liguri nell'area a sud del M. Cetona (Toscana meridionale). Atti Soc. Tosc. Sc. Nat., Mem., Ser. A, 84, 25-60.

Daniele G. \& Bianchi L. (1995) - Studio petrografico delle Arenarie di Ostia della media Val di Taro e loro confronto con arenarie di altre successioni. Mem. Accad. Lun. delle Sc. "G. Capellini", 64/65, 131-148.

Decandia F.A., Lazzarotto A. \& LiotTA D. (1993) - La «Serie ridotta» nel quadro della evoluzione geologica della Toscana Meridionale. Mem. Soc. Geol. It., 49, 181-191.

Decandia F.A., Lazzarotto A. \& Liotta D. (2001) - Structural features of the Southern Tuscany, Italy. Ofioliti, 26, 287-300.

Elter P. (1975) - L'ensemble ligure. Bull. Soc. Géol. Fr., 17, 984-997.

Elter P., Giglia G., Tongiorgi M. \& Trevisan L. (1975) - Tensional and compressional areas in recent (Tortonian to present) evolution of Northern Apennines. Boll. Geofis. Teor. Appl., 42, 3-18.

Elter F.M. \& PANDeli E. (1991) - Alpine and Hercynian orogenic phases in the basement rocks of the Northern Apennines (Larderello geothermal field, Southern Tuscany, Italy). Ecl. Geol. Helv., 83, 241-264.

Fazzuoli M., Pandeli E. \& SANi F. (1994) - Considerations on the sedimentary and structural evolution of the Tuscan Domain since Early Liassic to Tortonian. Mem. Soc. Geol. It., 48, 31-50.

Ferrari L., Conticelli S., Burlamacchi L. \& MANetTi P. (1996) Volcanological evolution of the Monte Amiata, Southern Tuscany: new geological and petrochemical data. Acta Vulc., 8, 41-56.

Franceschelli M., Pandeli E., Puxeddu M., Porcu R. \& Fadda S. (1994) - Illite crystallinity in pelitic rocks from Northern Apennines (southern Tuscany and Umbria, Italy). N. Jb. Miner. Mh., 8, 367-384. 
Fontana D. \& Mantovani Uguzzoni M.P. (1987) - La frazione terrigena carbonatica nelle arenarie della Pietraforte (Cretaceo Superiore, Toscana Meridionale). Boll. Soc. Geol. It., 106, 173-181.

FonTANA D. (1991) - Detrital carbonate grains as provenante indicators in the Upper Cretaceous Pietraforte Formation (Northern Apennines). Sedimentology, 38, 1085-1095.

Gianelli G., Puxeddu M., Batini F., Bertini G., Dini I., Pandeli E. \& NicOLINI R. (1988) - Geological model of a young volcano plutonic system: the geothermal region of Monte Amiata (Tuscany, Italy). Geothermics, 17, 719-734.

Gradstein F.M., Ogg J.G., Schmitz M.D. \& OgG G.M. (2012) - The Geologic Time Scale 2012. Geoarabia, 18, 203.

Lavecchia G., Minelli G. \& Pialli G. (1987) - Contractional and extensional tectonics along the transect Lake Trasimeno-Pesaro (central Italy). In: Boriani A., Bonafede M., Piccardo G.B. \& Vai G.B. (eds.), The Lithosphere in Italy. Advanced in Earth Sciences Research, Accademia Nazionale dei Lincei, 80, 177-194.

Lazzarotto A., Sandrelli F., Foresi L.M., Mazzei R., SalvatoriNi G., Cornamusini G. \& Pascucci V. (2002) - Note illustrative della Carta Geologica d'Italia, alla scala 1:50.000, Foglio 295-Pomarance. Servizio Geologico d'Italia, 140 pp.

LiotтA D. (1991) - The Arbia-Val Marecchia line, Northern Apennines. Ecl. Geol. Helv., 84, 413-430.

Marcucci M. \& PAsserini P. (1980) - Nannofossil dating of postophiolite magmatic activity at Castiglioncello del Trinoro, Southern Tuscany. Ofioliti, 5, 79-96.

Marcucci M. \& PASSERINI P. (1982) - The age of the Castiglioncello del Trinoro magmatic phase in Southern Tuscany: a progress report and its relations to Cretaceous orogenesis in Corsica. Ofioliti, 7, 79-84.

Marino M. \& Monechi S. (1994) - Nuovi dati sull'età di alcuni Flysch ad Helmintoidi cretacei e terziari dell'Appennino Settentrionale. Mem. Sci. Geol., 46, 43-77.

MARroni M. \& Perilli N. (1990) - The age of the ophiolite sedimentary cover from the Mt. Gottero Unit (Internal Ligurid Units, Northern Apennines): new data from Calcareous Nannofossils. Ofioliti, 15, 251-267.

Marroni M. (1991) - Deformation history of the Mt.Gottero Unit (Internal Liguride Units, Northern Apennines). Boll. Soc. Geol. It., 110, $727-736$.

Marroni M., Molli G., Ottria G. \& Pandolfi L. (2001) - Tectonosedimentary evolution of the External Liguride units (Nothern Appennines, Italy): insights in the pre-collisional history of a fossil ocean-continent transition zone. Geodin. Acta, 14, 307-320.

Marroni M., Molli G., Montanini A., Ottria G., Pandolfi L. \& TRIBUZIO R. (2002) - The External Liguride units (Northern Apennine, Italy): from rifting to convergence history of a fossil oceancontinent transition zone. Ofioliti, 27, 119-132

Marroni M., Pandolfi L. \& Meneghini F. (2004) - From accretion to exhumation in a fossil accretionary wedge: a case history from Gottero Unit (Northern Apennines, Italy). Geodin. Acta, 17, 41-53.

Marroni M., Meneghini F. \& Pandolfi L. (2010) - Anatomy of the Ligure-Piemontese subduction system: evidence from Late Cretaceous-middle Eocene convergent margin depositsin the Northern Apennines, Italy. Int. Geol. Rev., 1, 1-33.

MARTINI E. (1971) - Standard Tertiary and Quaternary calcareous nannoplankton zonation. In: A. Farinacci (ed.), Proceedings of the Second Planktonic Conference Roma 1970, Edizioni Tecnoscienza, Roma, 2, 739-785.

MARTINI I.P. \& SAGRI M. (1993) - Tectono sedimentary characteristics of late Miocene-Quaternary extensional basins of the Northern Apennines, Italy. Earth Sciences Reviews, 34, 197-233.

Martini I.P., SAgRi M. \& Colella A. (2001) - Neogene-Quaternary Basins of the Inner Apennines and Calabrian Arc. In: G.B. Vai \& I.P. Martini (eds.), Anatomy of an orogen: the Apennines and adjacent Mediterranean basins. Kluver Academic Publishers, Dordrecht/Boston/London, 375-400.

Mazzuoli R. \& Pratesi M. (1963) - Rilevamento e studio chimico petrografico delle rocce vulcaniche del Monte Amiata. Atti Soc. Tosc. Sc. Nat. Mem., Ser. A., 70, 355-429.

Meneghini F., Marroni M. \& Pandolfi L. (2007) - Fluid flow during accretion in sediment-dominated margins: evidences of a high-permeability fossil fault zone from the Internal Ligurian accretionary units of the northern Apennines, Italy. Journ. of Struct. Geol., 29, 515-529.

Molli G. (2008) - Northern Apennine-Corsica orogenic system: an updated overview. Geological Society of London Special Pubblications, 298, 413-442

Mutti E. (1992) - Turbidite Sandstones. Agip, Instituto di Geologia, Università di Parma, San Donato Milanese, 275 pp.

OKADA H. \& BUKRY D. (1980) - Supplementary modification and introduction of code numbers to the low latitude coccolith biostratigraphic zonation. Mar. Microp., 5, 321-325.

ORI G.G. \& FRIEND P.F. (1984) - Sedimentary basins formed and carried piggy-back on active thrust sheets. Geology, 12, 475-478.

Pandeli E., Bertini G., Castellucci P., Morelli M. \& Monechi S. (2005) - The Ligurian Sub-Ligurian and Tuscan Units of the Monte Amiata geothermal region (Southeastern Tuscany): new stratigraphic and tectonic data. Boll. Soc. Geol. Ital., 3, 55-71.

Pandeli E., Puxeddu M., Gianelli G., Bertini G. \& Castellucci P. (1988) - Paleozoic sequences crossed by deep drillings in the Monte Amiata Geothermal Region (Italy). Boll. Soc. Geol. Ital., 107, 593-606.

Pasquaré G., Chiesa S., Vezzoli L. \& Zanchi A. (1983) - Evoluzione paleogeografica e strutturale di parte della Toscana meridionale a partire dal Miocene superiore. Mem. Soc. Geol. It., 25, 147-157.

PERILLI N. (2007) - Lower cretaceous nannofossil biostratigraphy of the Calpionella Limestone and the Palombini Shale in Southern Tuscany (Italy). Rev. Esp. Paleont., 12, 1-14.

Perilli N., Catanzariti R., Cascella A. \& Nannini D. (2009) - The Calcari di Groppo del Vescovo Formation (Subligurian Units; Northern Apennines, Italy): new dating based on calcareous nannofossils. Atti Soc. Tosc. Sci. Nat., 114, 75-83.

PrinciPI G. \& Treves B. (1984) - Il sistema Corso-Appenninico come prisma di accrezione. Riflessi sul problema generale del limite Alpi-Appennini. Mem. Soc. Geol. It., 28, 549-576.

RAMSAY J.G. (1980) - The crack-seal mechanism of rock deformation. Nature, 284, 135-139.

RAMSAY J.G. (1967) - Folding and fracturing of rocks. McGraw \& Hill (ed.), $568 \mathrm{pp}$.

Regione Toscana (2014) - Carta geologica della Regione Toscana. http://www.regione.toscana.it/-/carta-geologica.

Ricci Lucchi F. (1986) - The Oligocene to recent forel \& basins of the northern Apennines. In: P. Allen \& P. Homewood (eds.), Foreland Basin, Int. Assoc. Sedimentol. Spec. Publ., 8, 105-139.

Stoppa F., Rukhlov A.S., Bell K., SchiazZa M. \& Vichi G. (2014) Lamprophyres of Italy: early Cretaceous alkaline lamprophyres of Southern Tuscany, Italy. Lithos, 188, 97-112.

SissingH W. (1977) - Biostratigraphy of Cretaceous calcareous nannoplankton. Geologie en Mijnbouw, 56, 37-65.

Treves B. (1984) - Orogenic belt as accretionary prism: the example of the Northern Apennines. Ofioliti, 9, 577-618.

VAlloni R. \& ZUFFA G.G. (1984) - Provenance changes for arenaceous formations of the northern Apennines, Italy. Geol. Soc. Amer. Bull., 95, 1035-1039.

Vescovi P., Fornaciari E., Rio D. \& VAlloni R. (1999) - The basal complex stratigraphy of the Helminthoid Monte Cassio Flysch; a key to the Eoalpine tectonics of the Northern Apennines. Riv. It. di Paleont. e Strat., 105, 101-128. 